Research paper

\title{
Volatile abundances and oxygen isotopes in basaltic to dacitic lavas on mid-ocean ridges: The role of assimilation at spreading centers
}

\author{
V.D. Wanless ${ }^{\text {a,* }}$, M.R. Perfit ${ }^{\text {a }}$, W.I. Ridley ${ }^{\text {b,c }}$, P.J. Wallace ${ }^{d}$, C.B. Grimes ${ }^{\text {e, }}{ }^{\text {, E.M. Klein }}{ }^{\mathrm{f}}$ \\ a Department of Geological Sciences, University of Florida, Gainesville, FL 32611, United States \\ b US Geological Survey, Denver, CO 80225, United States \\ ${ }^{c}$ National Science Foundation, Arlington, VA 22230, United States \\ d Department of Geological Sciences, University of Oregon, Eugene, OR 97403, United States \\ e Department of Geosciences, Mississippi State, MS 39762, United States \\ ${ }^{\mathrm{f}}$ Nicholas School of the Environment, Duke University, Durham, NC 27708, United States
}

\section{A R T I C L E I N F O}

\section{Article history:}

Received 2 November 2010

Received in revised form 25 May 2011

Accepted 26 May 2011

Available online $\mathrm{xxxx}$

Editor: L. Reisberg

\section{Keywords:}

Assimilation

Chlorine

Dacite

Mid-ocean ridge

Oxygen isotopes

Volatiles

\begin{abstract}
A B S T R A C T
Most geochemical variability in MOR basalts is consistent with low- to moderate-pressure fractional crystallization of various mantle-derived parental melts. However, our geochemical data from MOR highsilica glasses, including new volatile and oxygen isotope data, suggest that assimilation of altered crustal material plays a significant role in the petrogenesis of dacites and may be important in the formation of basaltic lavas at MOR in general. MOR high-silica andesites and dacites from diverse areas show remarkably similar major element trends, incompatible trace element enrichments, and isotopic signatures suggesting similar processes control their chemistry. In particular, very high $\mathrm{Cl}$ and elevated $\mathrm{H}_{2} \mathrm{O}$ concentrations and relatively light oxygen isotope ratios ( $5.8 \%$ vs. expected values of $\sim 6.8 \%$ o) in fresh dacite glasses can be explained by contamination of magmas from a component of ocean crust altered by hydrothermal fluids. Crystallization of silicate phases and Fe-oxides causes an increase in $\delta^{18} \mathrm{O}$ in residual magma, but assimilation of material initially altered at high temperatures results in lower $\delta^{18} \mathrm{O}$ values. The observed geochemical signatures can be explained by extreme fractional crystallization of a MOR basalt parent combined with partial melting and assimilation (AFC) of amphibole-bearing altered oceanic crust. The MOR dacitic lavas do not appear to be simply the extrusive equivalent of oceanic plagiogranites. The combination of partial melting and assimilation produces a distinct geochemical signature that includes higher incompatible trace element abundances and distinct trace element ratios relative to those observed in plagiogranites.
\end{abstract}

(c) 2011 Elsevier B.V. All rights reserved.

\section{Introduction}

Crustal assimilation has been proposed in the petrogenesis of some mid-ocean ridge (MOR) magmas (e.g., O'Hara, 1977; Michael and Schilling, 1989; Michael and Cornell, 1998), but for several reasons it is largely ignored as a primary igneous process in ridge settings. First, contamination is commonly overlooked because most geochemical variations in MOR lavas can be readily explained by fractional crystallization, variations in mantle melting parameters, or differences in mantle source compositions. Second, the low volumes of melt assimilated compared to the more voluminous mid-ocean ridge basalt (MORB) magma makes assimilation difficult to identify in the erupted lavas. Third, the magma and wall rock may have similar major and trace element compositions, resulting in melts that are geochemically

* Corresponding author at: Department of Geology and Geophysics, MS\#24, WHOI, Woods Hole, MA 02541, United States. Tel.: +1 5082893922.

E-mail address: dwanless@whoi.edu (V.D. Wanless).

Previous address: Department of Geological Science, University of Wisconsin, Madison, WI 53706, United States. difficult to discriminate from typical MORB lavas. However, variable degrees of hydrothermal alteration of basaltic crust can produce significant changes in fluid mobile elements and ratios of low-mass isotopes in oceanic rocks depending on the water/rock ratios (e.g., Alt and Teagle, 2000). Therefore, components that are particularly sensitive to seawater interaction, such as $\mathrm{Cl}, \mathrm{U}, \mathrm{H}_{2} \mathrm{O}$, and oxygen isotopes, can be used to determine the extent to which crustal assimilation is involved in MOR magmatism.

Contamination of MOR magmas by seawater-altered rocks was first proposed based on excess $\mathrm{Cl}$ in MORB glasses (Michael and Schilling, 1989; Michael and Cornell, 1998). The elevated Cl concentrations compared to elements of similar incompatibility (K, Nb, Ti) in fresh MORB glass cannot be explained by post-eruption alteration or fractional crystallization and are instead attributed to assimilation of a seawater-derived component such as saline brines or altered ocean crust (Michael and Schilling, 1989; Michael and Cornell, 1998). Subsequently, $\mathrm{Cl}$ over-enrichment has been identified in many submarine settings, including MOR (Perfit et al., 1999; Coogan et al., 2003; le Roux et al., 2006; Wanless et al., 2010), back-arc basins (Kent et al., 2002; Sun et al., 2007) and ocean islands (e.g. Kent et al., 1999). 
Despite the clear evidence of assimilation in these lavas, many models for the magmatic plumbing system at MORs continue to ignore this process.

An alternate approach to identifying crustal contamination on MORs is through oxygen isotope ratios. Low oxygen isotope ratios relative to mantle values are observed in many lavas from Icelandic volcanoes (e.g. Gautason and Muehlenbach, 1998). Lower-than-mantle values have also been observed in olivine phenocrysts and in Hawaiian glasses and are attributed to assimilation of altered Pacific crust (Eiler et al., 1996; Garcia et al., 1998). Decreases in $\delta^{18} \mathrm{O}$ relative to primary mantle-like values are attributed to contamination by crustal rocks altered at temperatures $>200-250{ }^{\circ} \mathrm{C}$, which have lower values due to the temperature-dependent fractionation of oxygen isotopes between seawater and mineral phases in ocean crust during high-temperature hydrothermal alteration (Muehlenbach and Clayton, 1972; Alt et al., 1996). Subsequent assimilation of altered crust in contact with MOR melt should lower the oxygen isotope ratios of the resulting magma. If the mass of assimilant relative to the parent magma is low it may be difficult to detect a decrease in the oxygen isotope ratios. However, oxygen isotopes may be substantially modified in magmas that have experienced more significant degrees of assimilation.

Here, we examine $\mathrm{H}_{2} \mathrm{O}, \mathrm{CO}_{2}$ and $\mathrm{S}$ concentrations and oxygen isotope ratios from a suite of lavas collected at the $9^{\circ} \mathrm{N}$ overlapping spreading center (OSC) on the East Pacific Rise (EPR) to further evaluate their petrogenesis, with specific emphasis on the role of crustal assimilation, and to test the more general hypothesis that assimilation is a common process in MOR magmatic systems. This suite of lavas displays a nearly continuous range of compositions from basalts to dacites, including one of the most evolved lava compositions sampled on a MOR (67.46 wt.\% $\mathrm{SiO}_{2}$ ). Major and trace element data and $\mathrm{Cl}$ concentrations indicate that assimilation of altered ocean crust is a critical process for the formation of MOR dacites (Wanless et al., 2010); a process that should also be reflected in the $\mathrm{H}_{2} \mathrm{O}$ and $\mathrm{CO}_{2}$ concentrations and oxygen isotope ratios. $\mathrm{H}_{2} \mathrm{O}, \mathrm{CO}_{2}$ and $\mathrm{S}$ concentrations are used to provide information on degassing of high-silica magmas during extensive fractional crystallization and eruption on the seafloor. We use $\mathrm{Cl} / \mathrm{K}_{2} \mathrm{O}$ and $\mathrm{Ce} / \mathrm{H}_{2} \mathrm{O}$ ratios to constrain the composition of the assimilant, which may be altered ocean crust, saline brines and/or seawater.

\section{Background}

\subsection{Geologic setting}

The $9^{\circ} \mathrm{N}$ OSC (Fig. 1) is located between the Clipperton and Siquieros transform faults on the EPR. It is a second order ridge discontinuity consisting of limbs that overlap by $\sim 27 \mathrm{~km}$ and offset the ridge axis $\sim 8 \mathrm{~km}$ from east to west (Sempere and Macdonald, 1986). The OSC has been migrating southward at a rate of approximately $42 \mathrm{~km} / \mathrm{Myr}$ such that the eastern limb propagates into older crust and the western limb recedes or dies (Macdonald and Fox, 1983; Carbotte and Macdonald, 1992).

The $9^{\circ} \mathrm{N}$ OSC is one of the most extensively studied OSCs on the MOR system. It has been the focus of several geophysical studies (Detrick et al., 1987; Harding et al., 1993; Kent et al., 1993, 2000; Bazin et al., 2001; Dunn et al., 2001; Tong et al., 2002), which have produced the first 3D multi-channel seismic survey of a mid-ocean ridge (Kent et al., 2000) and a 3D seismic refraction study (Dunn et al., 2001). These studies reveal shallow melt lenses beneath both limbs of the OSC and in the interlimb region north of the overlap basin (Kent et al., 2000). The western, receding limb melt lens is narrow and shows no significant variation in depth along axis (Kent et al., 2000), while the melt lens beneath the eastern, propagating limb shows variations in both width and depth. Beneath the southern portion of the east limb the melt lens is narrower and deeper than the rest of the eastern ridge axis, plunging $\sim 500 \mathrm{~m}$ southward over $\sim 6 \mathrm{~km}$ (Kent et al., 2000). North of the overlap basin, the melt lens is anomalously wide ( $>4 \mathrm{~km})$ and is not centered directly over the ridge axis, instead extending from the axis $\sim 4 \mathrm{~km}$ to the west (Kent et al., 2000; Tong et al., 2002). Although the depth of the lens varies along axis, according to interpretation of seismic data, the top of the melt lens appears to track the base of the sheeted dikes, at approximately $1.5-2 \mathrm{~km}$ beneath the seafloor (Kent et al., 2000; Tong et al., 2002).

The first lava sampling in this region occurred during the CHEPR dredging and wax coring cruise that recovered several high-silica lavas, along with basalts and FeTi basalts (Langmuir et al., 1986). More recently, the $9^{\circ} \mathrm{N}$ OSC was the focus of the MEDUSA2007 research cruise (AT15-17), which completed detailed mapping using the DSL120A side-scan system (White et al., 2009), and the WHOI TowCam (Fornari, 2003) and extensive sampling using the ROV Jason2, (Wanless et al., 2010). Results of this cruise revealed that the region has erupted a range of rock types from basalts to dacites, but that high-silica lavas are confined to the eastern propagating limb of the OSC (Wanless et al., 2010). More evolved compositions on MOR are often associated with ridge propagation, where magmas are in contact with older volcanic crust (e.g., Christie and Sinton, 1981). The andesites and dacites were primarily collected north of $9^{\circ} 06^{\prime} \mathrm{N}$ either on-axis or on the flanks of the axial graben (Fig. 1). They erupted above the eastern edge of the seismically imaged wide melt lens. Several andesites/dacites were collected along a linear pillow mound that hosted the only active hydrothermal venting observed at the OSC. Lavas erupted at the OSC are dominantly ferrobasalts in contrast to the more MgO-rich MORB lavas that dominate the $9^{\circ} 15^{\prime} \mathrm{N}$ to $10^{\circ} \mathrm{N}$ section of the EPR (Batiza and Niu, 1992; Perfit et al., 1994; Smith et al., 2001; Goss et al., 2010).

\subsection{Evidence of assimilation on MOR}

Fractional crystallization is likely the primary process involved in basalt differentiation on MORs, however, there is geochemical, observational, and experimental evidence of assimilation occurring in these settings. As noted above, elevated $\mathrm{Cl}$ concentrations in some MORB cannot be a consequence of fractional crystallization alone and are instead explained by assimilation (Michael and Schilling, 1989; le Roux et al., 2006). Experimental studies suggest that low-degree partial melting of the upper ocean crust is possible and may account for the ubiquitous presence of plagiogranite veins throughout the ocean crust (Koepke et al., 2007). This is supported by observations of the transition zone between the gabbro (frozen melt lens) and sheeted dike complex in ophiolites, which show evidence of partial melting of wall rock (e.g. Coogan, 2003).

Assimilation is also an important process in the petrogenesis of dacites on MOR. Previous geochemical studies of dacites erupted at the $9^{\circ} \mathrm{N}$ OSC have used major and trace element concentrations in conjunction with petrologic modeling to show that extensive fractional crystallization (up to 95\%) alone cannot explain the major and trace element concentrations of the dacitic lavas (Wanless et al., 2010). Instead, compositions of high-silica lavas (including elevated chlorine concentrations) suggest that incorporation of a seawater-altered component (i.e., altered oceanic crust, seawater, and/or brines) is important in their petrogenesis. Thus it can be concluded that the petrogenesis of MOR dacites requires melting and assimilation of altered crustal material into a fractionally crystallizing magma chamber (i.e., an assimilation and fractional crystallization process; AFC).

\subsection{Composition of potential assimilants}

Possible sources of assimilants include seawater modified by hydrothermal circulation, saline brines stored within the crust, and/or altered crustal material (gabbros or sheeted dikes). Saline brines form from high temperature phase separation of seawater during hydrothermal circulation (e.g., Berndt and Seyfreid, 1990) and may be trapped along grain boundaries or in pore spaces within the ocean 


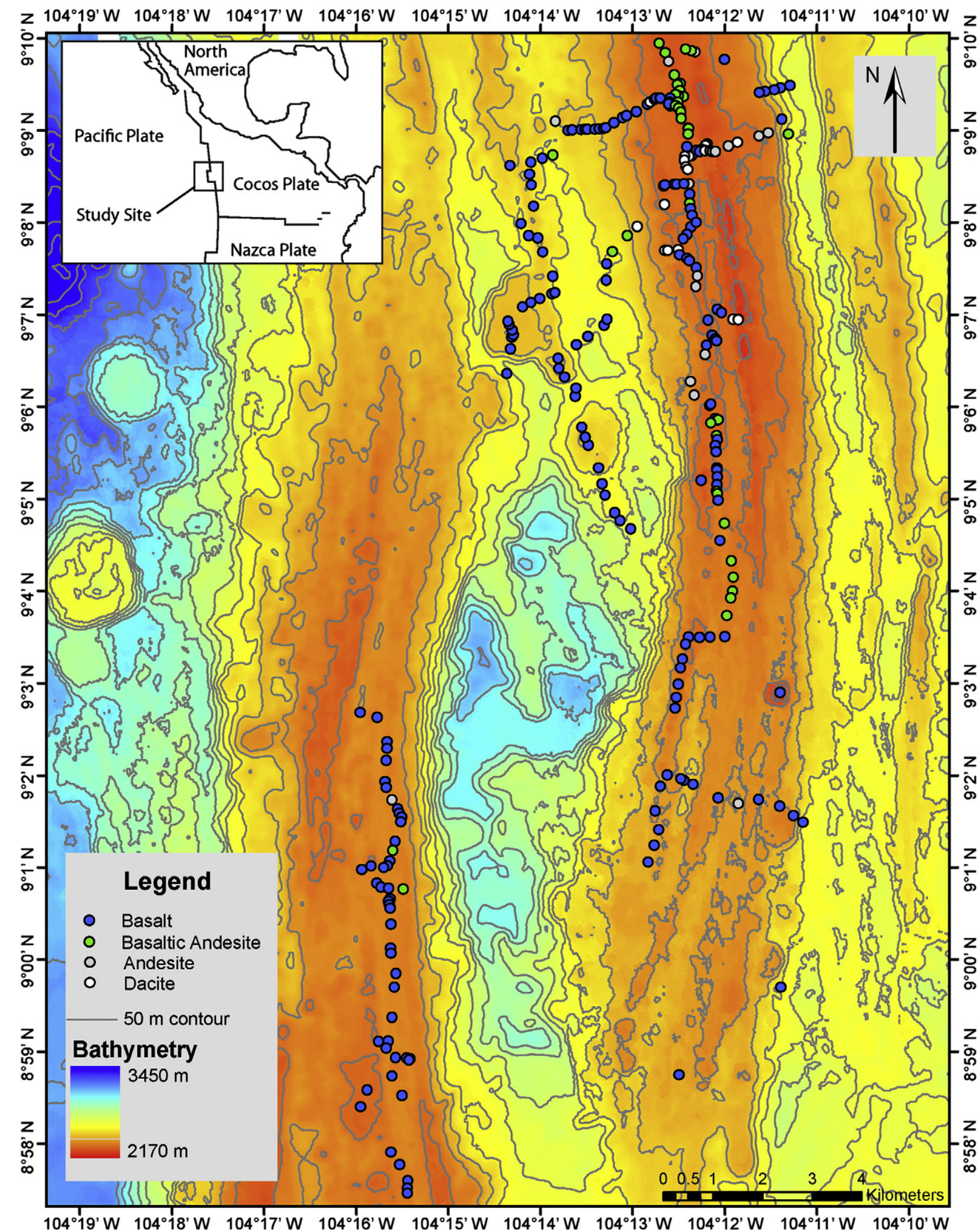

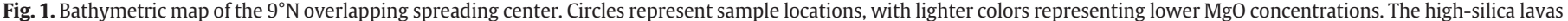
are primarily confined to the eastern propagating limb, north of $\sim 9^{\circ} 06^{\prime} \mathrm{N}$. 
crust (Michael and Schilling, 1989). They are thought to be a relatively common component of the upper ocean crust, though the composition and location within the crust remains largely unconstrained. Due to the limited stability of saline brines, it has been difficult to ascertain their exact compositions. However, they have relatively high concentrations of $\mathrm{H}_{2} \mathrm{O}, \mathrm{NaCl}, \mathrm{Sr}, \mathrm{Ca}$, and $\mathrm{K}_{2} \mathrm{O}$ (Berndt and Seyfreid, 1990; Von Damm et al., 1997) compared to MORB. The percent of $\mathrm{NaCl}$ in the brine may be highly variable, but up to $50 \%$ (30 wt.\% $\mathrm{Cl}$ ) has been estimated by measurements of fluid inclusions (Kelley and Delaney, 1987). Therefore, assimilation of brine material should increase $\mathrm{Cl}, \mathrm{Na}_{2} \mathrm{O}$, and $\mathrm{K}_{2} \mathrm{O}$ concentrations of the melt, although the exact mechanism of assimilation is not understood.

The bulk composition and mineralogy of altered crustal material may vary, depending on the temperature and pressure of alteration and the fluid/rock ratios (Alt et al., 1986). Constraints on the depth of assimilation come from studies of volatile concentrations in glasses (Michael and Cornell, 1998; le Roux et al., 2006) and textural observations in ophiolites (e.g. Gillis and Coogan, 2002), and are consistent with melting at the top of the shallow melt lens. The depth of the melt lens, however, may vary due to migration within crust over time and, therefore, the melt may interact with the upper gabbros and/ or lower sheeted dikes (Gillis, 2008). If alteration is caused by circulation of hydrothermal fluids, it is likely that this is largely restricted by permeability to the base of the sheeted dikes and uppermost gabbros of Layer 3. This is also consistent with observations from drill cores from lower sheeted dikes and upper gabbros that have experienced low- to medium-grade metamorphism (up to greenschist or amphibolite facies; Alt et al., 1986; Coogan et al., 2003). Although hydrothermal circulation has little effect on the major element chemistry, the lower sheeted dikes and upper gabbros commonly show lower $\mathrm{K}_{2} \mathrm{O}, \mathrm{Na}_{2} \mathrm{O}$ and $\delta^{18} \mathrm{O}$ values, variable $\mathrm{CO}_{2}$, higher $\mathrm{H}_{2} \mathrm{O}$ and $\mathrm{Cl}$ concentrations (e.g. Alt et al., 1996) and slight $\mathrm{S}$ depletion (e.g. Alt et al., 1989) compared to the extrusive volcanic layer.

\section{Analytical methods and results}

\subsection{Major and trace elements}

During the MEDUSA2007 research cruise, 275 glassy samples were collected from the $9^{\circ} \mathrm{N}$ OSC. Methods, standards and results from all major and trace element analyses are discussed in detail in Wanless et al. (2010) and are only briefly mentioned here. Glasses are fresh and primarily aphyric. Individual chips from each sample were handpicked to avoid any microphenocrysts and alteration. Major elements were analyzed on a JEOL 8900 Electron Microprobe at the USGS in Denver, Colorado. Each sample was analyzed 8 to 10 times and averages of these are reported here and in Wanless et al. (2010). The microprobe was calibrated using the USGS mineral standards and several in-house standards (JdF-D2, Reynolds, 1995; 2392-9, Smith et al., 2001; and USGS dacitic glass GSC) were used for secondary normalizations to account for instrumental drift (see Smith et al., 2001 for details). High-precision $\mathrm{Cl}, \mathrm{S}$ and $\mathrm{K}_{2} \mathrm{O}$ concentrations were determined using 200-second peak/100-second background counting times. The chlorine standard used was St 7820 Sodalite. Samples were analyzed for trace element concentrations on an Element2 Inductively Coupled Plasma Mass Spectrometer (ICP-MS) at the University of Florida (see Goss et al., 2010 for more analytical details). Concentration data and ratios used in this paper are listed in Table 1.

To simplify the discussion, we use the general terms "basalt and basaltic" to include basalts, ferrobasalts and FeTi basalts ( $<52$ wt.\% $\mathrm{SiO}_{2}$ ). The intermediate lavas include both basaltic andesites and andesites, with $\mathrm{SiO}_{2}$ concentrations that range from 52 to $57 \mathrm{wt} . \%$ and 57 to 62 wt.\%, respectively. Dacites have $>62$ wt.\% $\mathrm{SiO}_{2}$. $\mathrm{Cl}$ concentrations range from 0.01 to $0.07 \mathrm{wt}$.\% in the basalts and are systematically higher in the basaltic andesites ( 0.01 to $0.31 \mathrm{wt} . \%)$, andesites $(0.20$ to
0.42 wt.\%) and dacites ( 0.23 to 0.70 ; Fig. 2 ). $\mathrm{K}_{2} \mathrm{O}$ concentrations range from 0.13 to $1.37 \mathrm{wt}$ \% and increase with increasing $\mathrm{SiO}_{2}$ content. $\mathrm{K}_{2} \mathrm{O}$ ranges from 0.13 to 0.21 wt.\% in basalts, from 0.26 to $0.60 \mathrm{wt} . \%$ in basaltic andesites, from 0.63 to $0.83 \mathrm{wt} . \%$ in andesites and from 0.89 to 1.37 wt.\% in dacites (Fig. 2). Although $\mathrm{K}_{2} \mathrm{O}$ concentrations can be relatively high, all samples discussed here can be considered incompatible element depleted "normal" MORB (N-MORB) or their differentiates. $\mathrm{Cl} / \mathrm{K}_{2} \mathrm{O}$ ratios exhibit a marked increase from 0.04 to 0.60 with increased differentiation (Figs. 3 and 4 ). S concentrations range from 1898 to $345 \mathrm{ppm}$, with the highest concentrations observed in FeTi basalts and the lowest in the dacites (Fig. 5).

\subsection{Volatile elements}

A representative subset of 20 samples (covering the range of rock types) from the $9^{\circ} \mathrm{N}$ OSC was selected for volatile analyses (Table 1 ). Several glass chips were handpicked from each sample, avoiding alteration and microphenocrysts. Samples were analyzed for $\mathrm{H}_{2} \mathrm{O}$ and $\mathrm{CO}_{2}$ concentrations by Fourier transform infrared (FTIR) spectroscopy at the University of Oregon (Johnson et al., 2009). Water concentrations were calculated either using the fundamental $\mathrm{OH}$ stretching vibration at $3570 \mathrm{~cm}^{-1}$ or from the average of the two molecular water peaks $\left(1630 \mathrm{~cm}^{-1}\right.$ and $\left.5200 \mathrm{~cm}^{-1}\right)$ and the $4500 \mathrm{~cm}^{-1} \mathrm{OH}^{-}$ peak. An absorption coefficient of $63 \mathrm{~L} / \mathrm{mol} \mathrm{cm}$ was used for the $3570 \mathrm{~cm}^{-1}$ peak (Dixon et al., 1995a,b), and absorption coefficients for the near-IR peaks were calculated based on major element concentrations following methods in Mandeville et al. (2002). $\mathrm{CO}_{2}$ concentrations were measured using the carbonate peaks at 1515 and $1430 \mathrm{~cm}^{-1}$, using background subtraction procedures described in Johnson et al. (2009) and absorption coefficients calculated from Dixon and Pan (1995). The detection limit for $\mathrm{CO}_{2}$ dissolved as carbonate is $\sim 25 \mathrm{ppm}$. Dacite spectra were checked for molecular $\mathrm{CO}_{2}$ $\left(2350 \mathrm{~cm}^{-1}\right)$. In most cases, the concentrations were below the minimum detection limit of 2-5 ppm. In a few samples with excellent background characteristics, molecular $\mathrm{CO}_{2}$ at the $1-2$ ppm level was measured.

Volatile concentrations are highly variable but are generally consistent with major element trends (Table 1 ). $\mathrm{H}_{2} \mathrm{O}$ concentrations range from 0.23 to $0.39 \mathrm{wt} . \%$ in basaltic glasses and from 0.24 to 1.56 in basaltic andesite samples (Fig. 2). Andesites have $\mathrm{H}_{2} \mathrm{O}$ concentrations from 0.99 to $1.50 \mathrm{wt} . \%$ and dacites from 1.53 to $2.35 \mathrm{wt} . \% . \mathrm{CO}_{2}$ concentrations in basaltic glasses range from 131 to $256 \mathrm{ppm}$ (Fig. 2). Two of the basaltic andesites had measurable $\mathrm{CO}_{2}$ concentrations (232 and $184 \mathrm{ppm}$ ), but all others had $\mathrm{CO}_{2}$ concentrations below the detection limit. Andesite and dacite $\mathrm{CO}_{2}$ concentrations are also below the detection limit. $\mathrm{H}_{2} \mathrm{O} / \mathrm{Ce}$ ratios, which involve elements with similar magmatic incompatibility, generally increase with increasing silica (Fig. 3), with maximum values of 188 in basalts, 235 in basaltic andesites, 258 in andesites and 288 in dacites. $\mathrm{H}_{2} \mathrm{O} / \mathrm{K}_{2} \mathrm{O}$ ratios vary from 0.095 to 2.59 , with the highest ratios observed in the basaltic andesites (Fig. 4).

\subsection{Oxygen isotope analyses and results}

Oxygen isotope ratios $\left(\delta^{18} \mathrm{O}\right.$, per mil notation) of 26 fresh, microphenocryst-free glass chips, covering the range of rock types (Table 1 ), were determined at the $\mathrm{CO}_{2}$-laser-fluorination laboratory at the University of Wisconsin, Madison, following methods described in Valley et al. (1995) and Spicuzza et al. (1998). Aliquots of 2.4-3.2 mg were treated with $\mathrm{BrF}_{5}$ overnight, and then individually heated with a $\mathrm{CO}_{2}$ laser in the presence of $\mathrm{BrF}_{5}$. Measurements were standardized with 4-5 analyses of UWG-2 garnet standard per day $\left(\delta^{18} \mathrm{O}=5.8 \%\right.$; Valley et al., 1995), and are reported in standard $\delta$-notation relative to Standard Mean Ocean Water (SMOW). Reproducibility of the standard during each session was better than $\pm 0.15 \%$ 。 (2SD). 
Table 1

Oxygen isotope, major and volatile element composition of lavas from the $9^{\circ} \mathrm{N}$ OSC

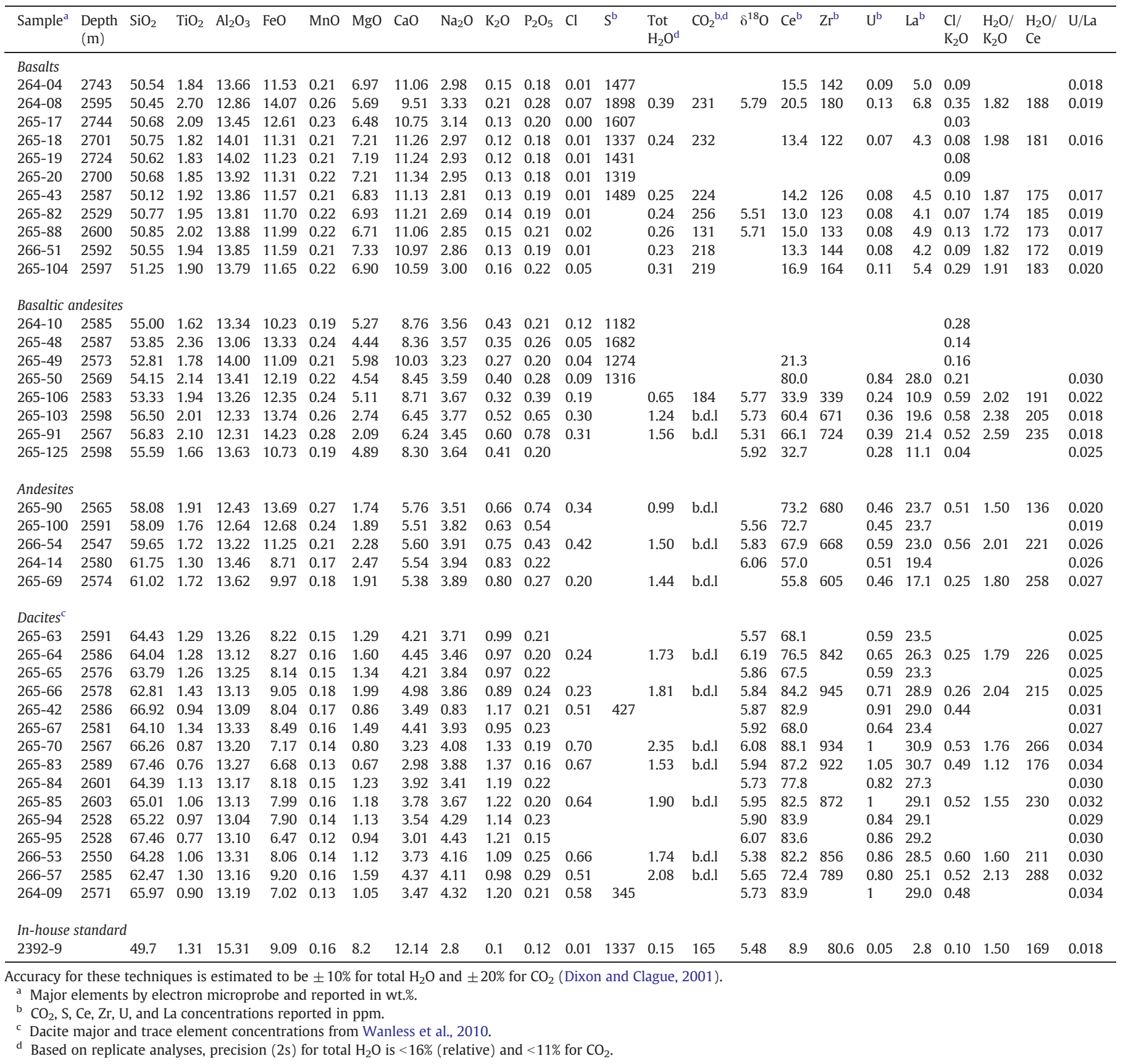

The $\delta^{18} \mathrm{O}$ values range from 5.3 to $6.2 \%$ in the OSC lavas with an average of $5.79 \%$ (Fig. 6). The basalts and basaltic andesites have similar oxygen isotope ratios, from 5.51 to $5.79 \%$ and 5.31 to $5.92 \%$ 。 respectively. The andesites and dacites have variable $\delta^{18} \mathrm{O}$ (5.38 to $6.19 \%$ ), with a mean of $5.86 \%$.

\section{Discussion}

\section{1. $\mathrm{CO}_{2}$ and $\mathrm{H}_{2} \mathrm{O}$ degassing}

Both $\mathrm{CO}_{2}$ and/or $\mathrm{H}_{2} \mathrm{O}$ can undergo variable amounts of degassing during ascent from the magma chamber to eruption on the seafloor. Observations and experimental solubility data indicate that $\mathrm{CO}_{2}$ degases more readily than $\mathrm{H}_{2} \mathrm{O}$ in basaltic melts. Nonetheless, many MORB glasses are supersaturated with $\mathrm{CO}_{2}$ at their submarine eruption depths (e.g., Dixon et al., 1988) indicating that the magma ascent rate is sufficiently rapid, the $\mathrm{CO}_{2}$ diffusion rate is sufficiently slow, and the magmas quench rapidly upon eruption, which can inhibit $\mathrm{CO}_{2}$ equilibration with the seafloor pressures. Therefore, in submarine settings, supersaturated $\mathrm{CO}_{2}$ concentrations are often equated with the minimum depth of storage of the melt prior to eruption (e.g., Dixon et al., 1988). The depth of last equilibration of vapor-saturated melts can be calculated using the $\mathrm{H}_{2} \mathrm{O}$ and $\mathrm{CO}_{2}$ solubility model of Dixon et al. (1995a,b), which is calibrated on experimental results at pressures and temperatures similar to MOR magmatic conditions. Vapor saturation pressures for the OSC basaltic and evolved samples were calculated using the VolatileCalc program (Newman and Lowenstern, 2002), which utilizes experimental results and formulations of Dixon et al. (1995a,b). This program is calibrated for both high-silica and basaltic compositions and requires an input of 

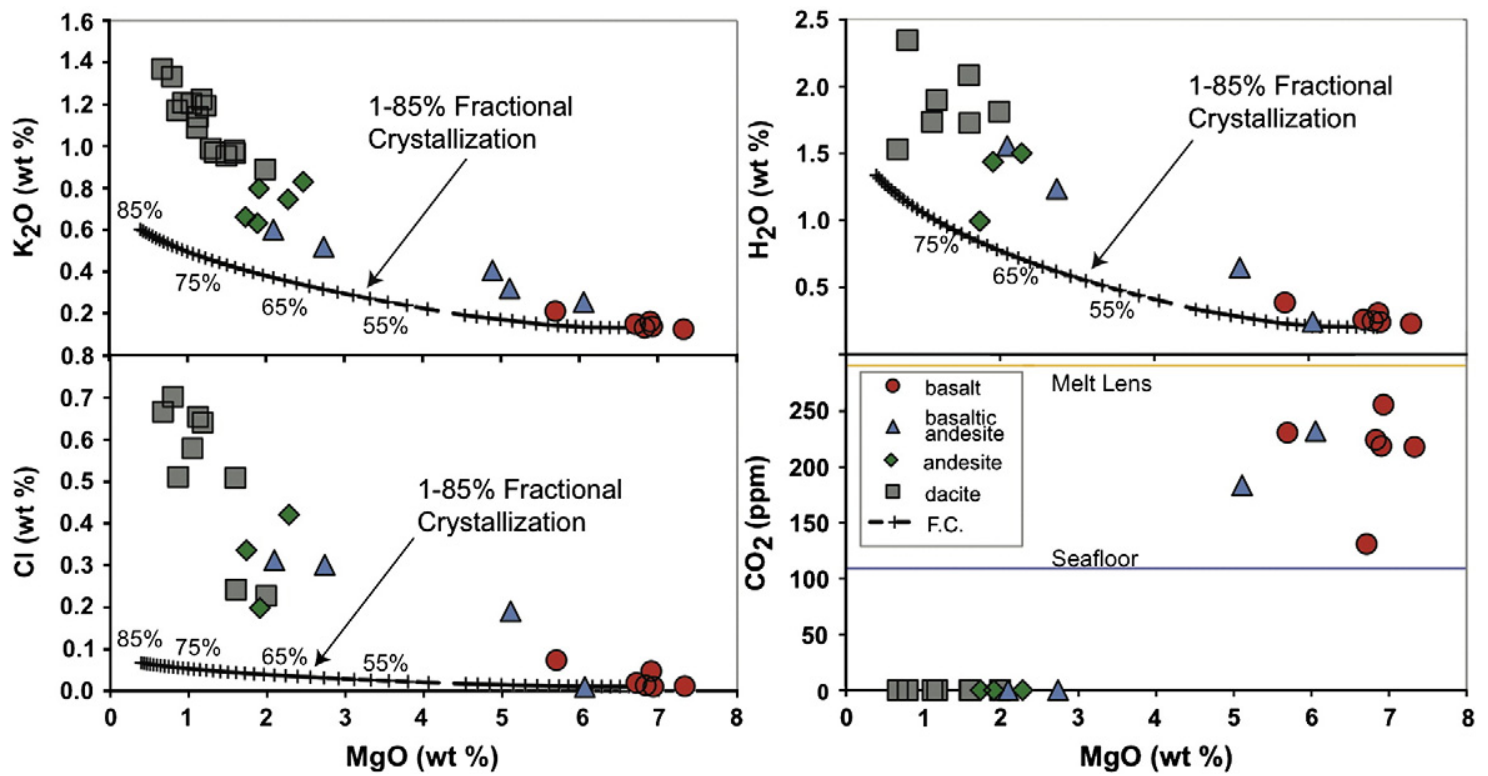

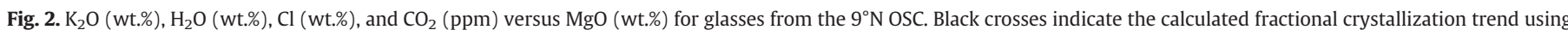
MELTS (Ghiorso and Sack, 1995). All dacitic lavas and several basaltic andesites lie above the calculated trend, indicating other processes are involved in their petrogenesis. $\mathrm{K}_{2} \mathrm{O}$ and $\mathrm{Cl}$ diagrams modified from Wanless et al., 2010.

silica content (62 and $49 \mathrm{wt} . \% \mathrm{SiO}_{2}$, respectively) and temperature of the magma (900 and $1200{ }^{\circ} \mathrm{C}$, respectively). Pressure estimates calculated using VolatileCalc are typically within $\pm 10 \%$ of values
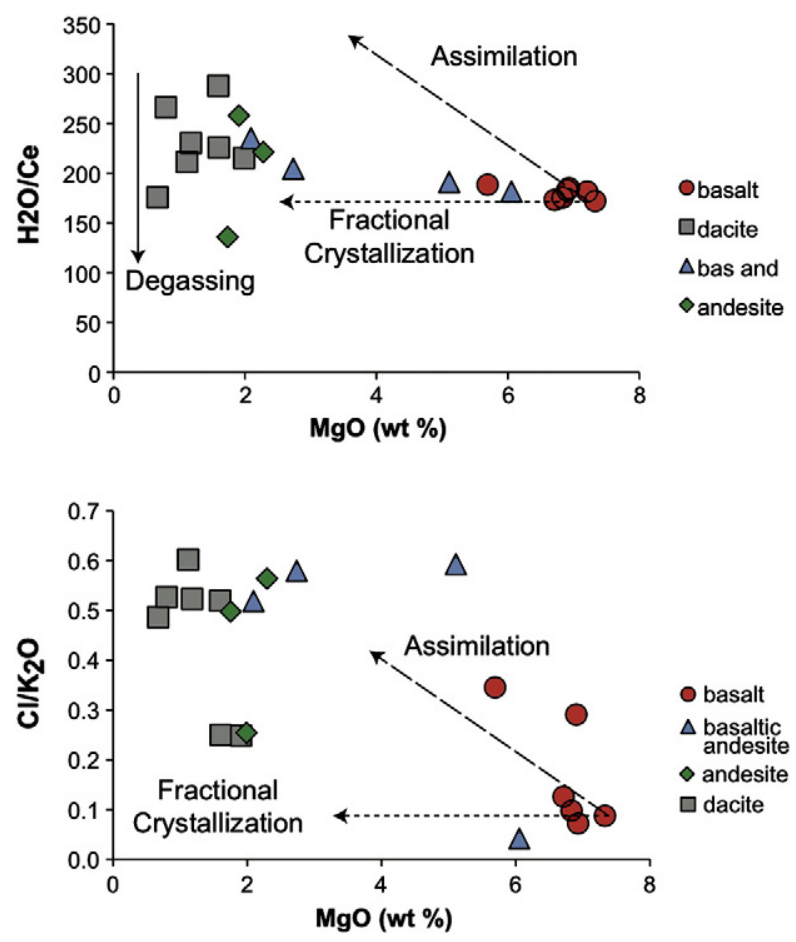

Fig. 3. $\mathrm{H}_{2} \mathrm{O} / \mathrm{Ce}$ and $\mathrm{Cl} / \mathrm{K}_{2} \mathrm{O}$ ratios versus $\mathrm{MgO}$ (wt.\%) for glasses from the $9^{\circ} \mathrm{N}$ OSC Generalized trends for assimilation and fractional crystallization are shown as straight dashed lines, although assimilation is likely to result in curved trends. In general, the andesites, dacites and most of the basaltic andesites have higher incompatible element ratios than the basaltic lavas, suggesting that they cannot result from fractional crystallization alone. Instead, they are consistent with assimilation of altered basalt. Low $\mathrm{H}_{2} \mathrm{O} / \mathrm{Ce}$ ratios are the result of variable degrees of $\mathrm{H}_{2} \mathrm{O}$ degassing. The andesites/ dacites with lower $\mathrm{Cl} / \mathrm{K}_{2} \mathrm{O}$ ratios $(\sim 0.24)$ were all collected from the same linear pillow mound that hosted the only observed active hydrothermal vent. calculated using other solubility models (Newman and Lowenstern, 2002).

$\mathrm{H}_{2} \mathrm{O}$ and $\mathrm{CO}_{2}$ concentrations in the OSC lavas indicate a range of equilibration pressures with a maximum of $\sim 550$ bar (Fig. 7). Most of the basaltic lavas are supersaturated with $\mathrm{CO}_{2}$ at their eruption depths, but they have equilibration pressures shallower than the top of the imaged melt lens ( $1.5 \mathrm{~km}$ or 670 bar; Kent et al., 2000), suggesting some degassing occurred during ascent and eruption on the seafloor. The vapor saturation calculations are similar to those of previous studies of basalts on MOR, which show equilibration within or above the top of the imaged melt lens (e.g., le Roux et al., 2006). This is consistent with relatively high ascent rates of basaltic magmas at the OSC and limited degassing of $\mathrm{CO}_{2}$ and $\mathrm{H}_{2} \mathrm{O}$.

In addition to completely degassing any initial $\mathrm{CO}_{2}$ that they may have contained, more $\mathrm{H}_{2} \mathrm{O}$-rich magmas, like the OSC andesites and dacites, may degas some $\mathrm{H}_{2} \mathrm{O}$ during ascent to the seafloor (Fig. 7). The high-silica lavas have equilibrium pressures, based on $\mathrm{H}_{2} \mathrm{O}$, that range from that of the seafloor ( 250 bar) to $\sim 500$ bar, similar to the pressure calculated for basalts but somewhat lower than expected for the top of the melt lens. If we assume that the andesites and dacites formed in the melt lens, at pressures consistent with the base of the sheeted dikes (Wanless et al., 2010), then this range of $\mathrm{H}_{2} \mathrm{O}$ concentrations suggests variable amounts of degassing during ascent and eruption on the seafloor. Degassing is consistent with the modest vesicularity of the high-silica lavas and correlates with lower $\mathrm{H}_{2} \mathrm{O} / \mathrm{Ce}$ ratios (Fig. 3).

$\mathrm{H}_{2} \mathrm{O}$ is enriched in the crust during hydrothermal circulation (e.g. Alt et al., 1996) due to formation of secondary hydrous minerals, therefore elevated $\mathrm{H}_{2} \mathrm{O}$ concentrations in fresh lavas may be an important signature of assimilation of altered crust. However, lower $\mathrm{H}_{2} \mathrm{O} / \mathrm{Ce}$ ratios (Fig. 3) and low $\mathrm{CO}_{2}$ contents in the high-silica glasses suggest that magma degassing is an important process during storage, ascent and/or eruption. Therefore, using $\mathrm{H}_{2} \mathrm{O}$ concentrations as a geochemical indicator of assimilation may be complicated by variable degrees of magma degassing prior to solidification on the seafloor.

\subsection{Evidence for assimilation from trace elements}

Liquid lines of descent (LLDs) calculations at $\mathrm{fO}_{2}=\mathrm{QFM}$ and $\mathrm{P}=1$ kbar (Wanless et al., 2010) suggest that fractional crystallization 


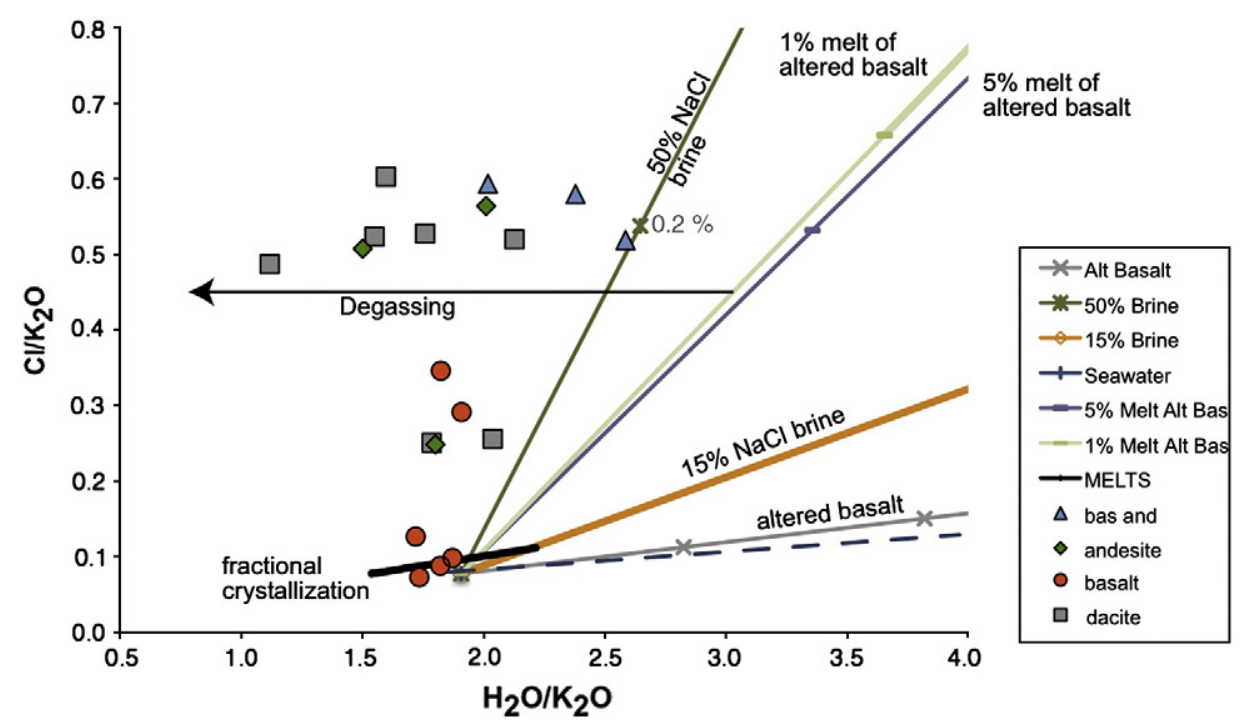

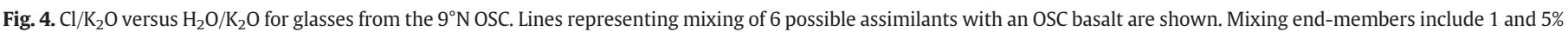

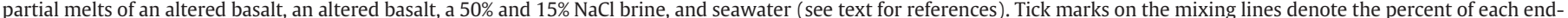

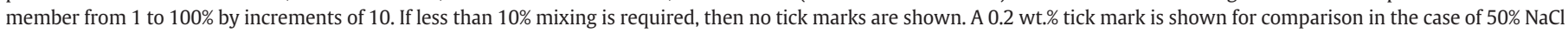

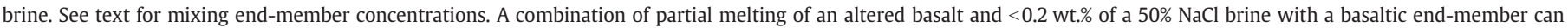
explain the formation of high-silica lavas on the OSC, if $\mathrm{H}_{2} \mathrm{O}$ has undergone variable amounts of degassing.

alone cannot account for the high $\mathrm{Cl}, \mathrm{K}_{2} \mathrm{O}$, and $\mathrm{H}_{2} \mathrm{O}$ concentrations observed in the MOR dacites, andesites or basaltic andesites (Fig. 2). $\mathrm{H}_{2} \mathrm{O}$ concentrations in the dacites are as much as two times greater and $\mathrm{Cl}$ concentrations are more than ten times greater than model predictions (Fig. 2). $\mathrm{H}_{2} \mathrm{O} / \mathrm{Ce}$ ratios, which should not change over a wide range of anhydrous fractional crystallization, are generally higher in dacites and extend to values $~ 1.5$ times higher than those of
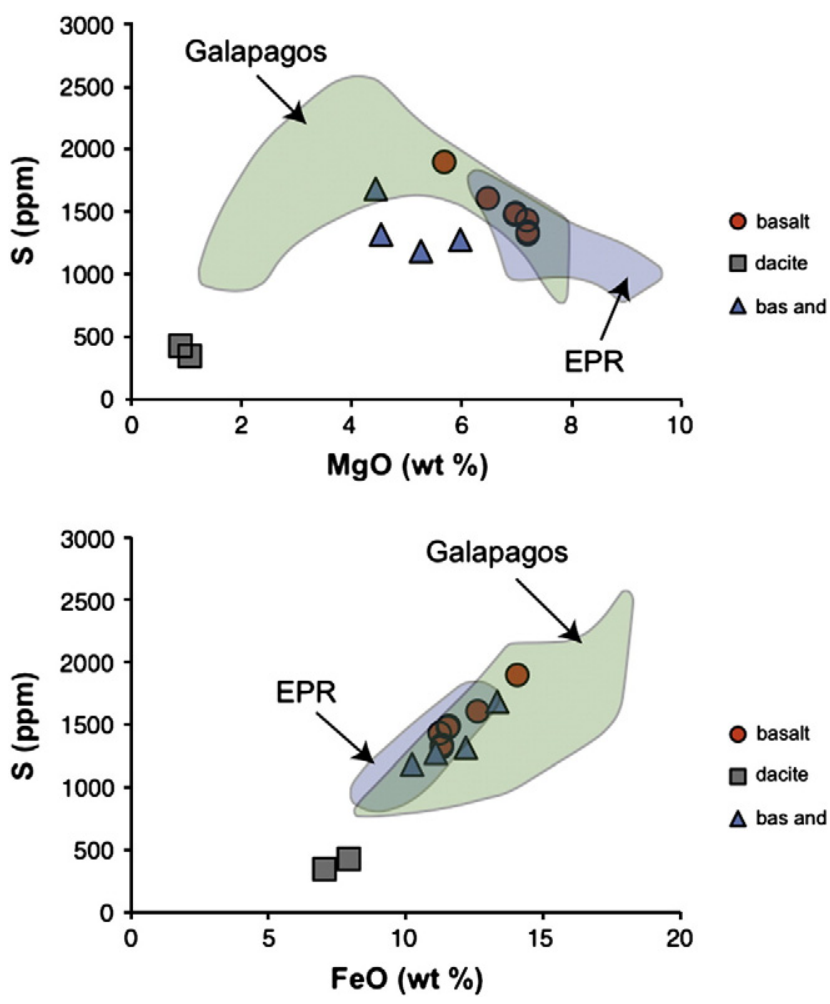

Fig. 5. $\mathrm{S}$ versus $\mathrm{MgO}$ and $\mathrm{FeO}$ for glasses from the $9^{\circ} \mathrm{N}$ OSC. MOR dacite glasses have low $\mathrm{S}$ contents, suggesting the formation of sulfides or degassing has occurred. Fields for lavas erupted at the Galapagos Spreading Center (Perfit et al., 1983) and EPR (le Roux et al., 2006) are also shown. the basalts, whereas basaltic andesites and andesites show a range of ratios (Fig. 3) $\mathrm{Cl} / \mathrm{K}_{2} \mathrm{O}$ values, which increase during hydrothermal alteration but remain relatively constant during fractional crystallization, are as much as seven times higher in the dacites than values measured in the least evolved basalts (Fig. 3). Interestingly, the andesites and dacites with lower $\mathrm{Cl}$ concentrations and $\mathrm{Cl} / \mathrm{K}_{2} \mathrm{O}<0.3$ were all recovered from a small pillow mound on-axis near the only active hydrothermal vent observed at the OSC, which suggests that the compositions of the assimilant may vary locally within the region.

Altered crust is enriched in chlorine during hydrothermal circulation of seawater (Michael and Schilling, 1989) due to the incorporation of Cl into nominally hydrous minerals. Altered sheeted dikes can have a wide range of chlorine composition ( 49 to $647 \mathrm{ppm}$ and a mean of $350 \mathrm{ppm}$ ) but these are generally higher than typical MORB concentrations (Sparks, 1995). The high $\mathrm{Cl}$ concentrations in the dacites are similar to model abundances produced by 1-15\% partial melting of altered basalt crust (Wanless et al., 2010). Although both $\mathrm{H}_{2} \mathrm{O}$ and $\mathrm{Cl}$ exhibit overenrichments compared to calculated fractional crystallization trends (Fig. 2), the $\mathrm{Cl}$ over-enrichment is much greater than that of $\mathrm{H}_{2} \mathrm{O} . \mathrm{Cl}$ degassing is insignificant during most submarine eruptions, due to the elevated of pressures at the seafloor, ( $250 \mathrm{bar})$ (Unni and Schilling, 1978; Webster et al., 1999). Therefore, the difference between these enrichment factors may be caused by variable amounts of $\mathrm{H}_{2} \mathrm{O}$ degassing, as discussed above or alternatively, the assimilant may have much higher $\mathrm{Cl} / \mathrm{H}_{2} \mathrm{O}$ compared to the uncontaminated magma, resulting in more enriched $\mathrm{Cl}$ concentrations.

le Roux et al. (2006) used $\mathrm{Cl} / \mathrm{Nb}$ ratios to assess the role of assimilation in MORB magmas because $\mathrm{Cl}$ and $\mathrm{Nb}$ have similar partition coefficients in basaltic systems and during seawater alteration these elements become decoupled, $\mathrm{Cl}$ being enriched in the altered material and $\mathrm{Nb}$ being immobile. Unfortunately, an added complication to using this approach is that advanced fractional crystallization in the OSC lavas results in precipitation of Fe-Ti oxides in which $\mathrm{Nb}$ is a compatible element. Consequently, the $\mathrm{Cl} / \mathrm{Nb}$ ratio changes and cannot be used as an alteration discriminant when highsilica lavas are involved. Here, we use $\mathrm{Cl} / \mathrm{K}_{2} \mathrm{O}$ (Fig. 3) because these elements also have broadly similar incompatibilities over a wide range of crystallization (e.g., Kent et al., 1999), and this ratio has been used in several studies to identify crustal contamination (e.g., Michael and Cornell, 1998; Kent et al., 1999). The siliceous lavas at the OSC 


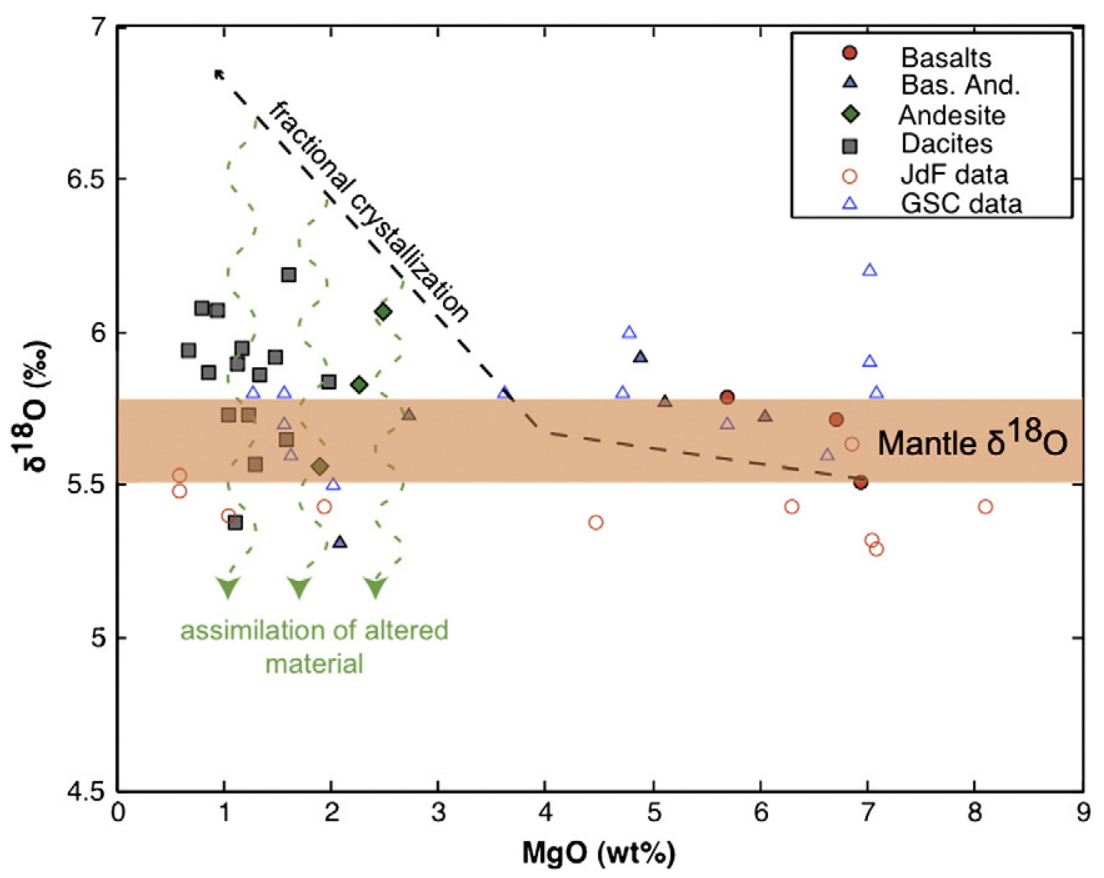

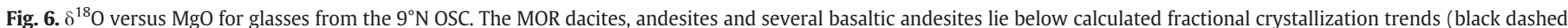

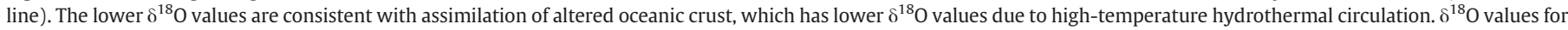
lavas from the Juan de Fuca ridge and Galapagos Spreading Center are shown for comparison.

have $\mathrm{Cl} / \mathrm{K}_{2} \mathrm{O}$ ratios three to seven times greater than the values observed in spatially related basalts (Fig. 3 ) and significantly higher than maximum mantle values (0.065) suggested by Michael and Cornell (1998). The elevated $\mathrm{Cl}$ abundances and incompatible element ratios in the evolved lavas therefore suggest they have been contaminated by crustal material and are consistent with assimilation of altered crust coupled with fractional crystallization (AFC) (Wanless et al., 2010). AFC processes will also produce an increase in incompatible trace element concentrations, particularly in elements enriched during seawater alteration, such as U (Wanless et al., 2010). This is evident in variations in U/La ratios, which are not affected by fractional crystallization but will increase due to assimilation of altered basalt (Fig. 8). These observations clearly indicate the operation of assimilation in the formation of basaltic andesites, andesites and dacites on MOR.

\subsection{Evidence for assimilation from oxygen isotopes}

Fractional crystallization of Fe-Ti oxides leads to an increase in $\delta^{18} \mathrm{O}$ values of evolving magmas (Taylor, 1968) because these phases, and to a lesser extent $\mathrm{Fe}-\mathrm{Mg}$ silicates, preferentially incorporate ${ }^{16} \mathrm{O}$ relative to ${ }^{18} \mathrm{O}$ (Taylor, 1968; Anderson et al., 1971; Muehlenbach and Byerly, 1982). During crystallization of MORB magma there is a slight increase in $\delta^{18} \mathrm{O}$ as the magma crystallizes ferromagnesian silicates, followed by a more rapid increase when $\mathrm{Fe}-\mathrm{Ti}$ oxides precipitate (Matsuhisa et al., 1973). Thus, advanced fractional crystallization should result in an increase of $\delta^{18} \mathrm{O}$ values by $0.5-1.5 \%$ in dacitic lavas (Bindeman, 2008, e.g., Muehlenbach and Byerly, 1982).

Using modal mineral proportions calculated from MELTS (Ghiorso and Sack, 1995) and oxygen isotope fractionation factors from Bindeman (2008), we calculated the change in $\delta^{18} \mathrm{O}$ during fractional

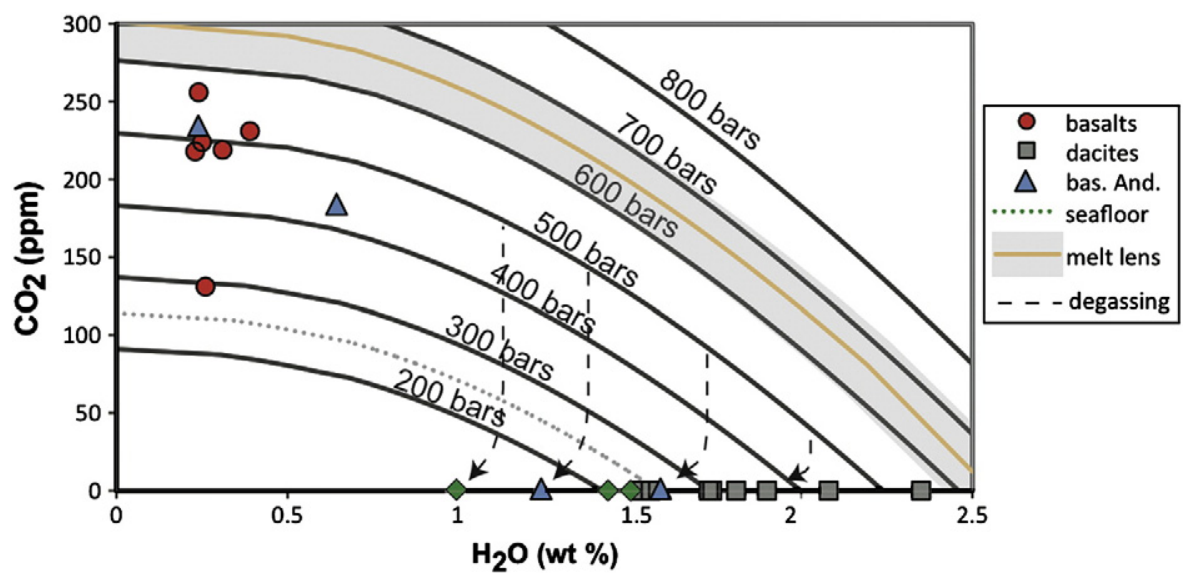

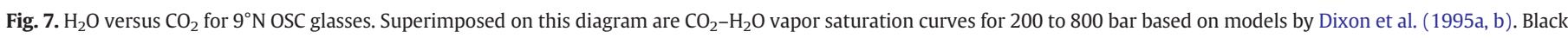

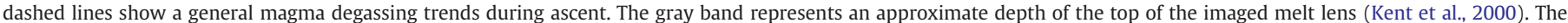

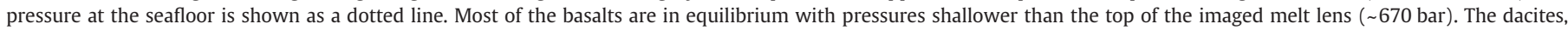

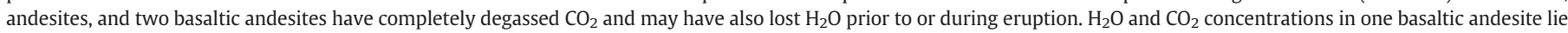
between the high-silica lavas and the basaltic lavas. 


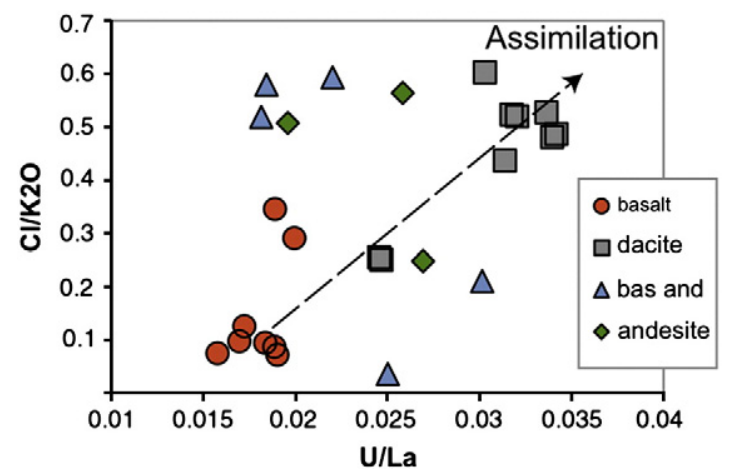

Fig. 8. $\mathrm{Cl} / \mathrm{K}_{2} \mathrm{O}$ versus $\mathrm{U} / \mathrm{La}$. Elevated $\mathrm{Cl} / \mathrm{K}_{2} \mathrm{O}$ values of the high-silica lavas can be explained by assimilation of altered crustal material that is enriched in $\mathrm{Cl}$, and $\mathrm{U}$ compared to $\mathrm{K}_{2} \mathrm{O}$ and La during seawater alteration. Several OSC basaltic lavas have elevated $\mathrm{Cl} / \mathrm{K}_{2} \mathrm{O}$ values, suggesting assimilation may also be important in their petrogenesis.

$\mathrm{U}$ and La data from Wanless et al., 2010.

crystallization of a MORB parental magma (Fig. 6). If the MOR dacites had formed through fractional crystallization, the $\delta^{18} \mathrm{O}$ should be $\sim 6.8 \%$, but the measured ratios are $\sim 1 \%$ o lower (dacite average $=$ $5.84 \%$ ), supporting the conclusion that the dacites could not exclusively form by fractional crystallization. Low values $\left(\delta^{18} \mathrm{O}=\right.$ 3.9-6.2\%) have also been observed in dacites erupted at the Galapagos Spreading Center (Perfit et al., 1999).

The temperature-dependent fractionation of oxygen isotopes between seawater $\left(\delta^{18} \mathrm{O}=0\right)$ and primary magmatic minerals (e.g., $\delta^{18} \mathrm{O} \sim 5.2-6.1 \%$ for olivine, clinopyroxene, and plagioclase) causes a bulk decrease in $\delta^{18} \mathrm{O}$ of ocean crust during high-temperature hydrothermal alteration, but increases the $\delta^{18} \mathrm{O}$ during low-temperature alteration $\left(<200-250{ }^{\circ} \mathrm{C}\right.$; Alt et al., 1996; Muehlenbach and Clayton, 1972). In the latter case, the fluid evolves to lower $\delta^{18} \mathrm{O}$ values in a closed system due to mass balance. This effect, together with the increase in temperature with depth, is obvious in profiles of oxygen isotope ratios in exposed sections of fast-spreading ocean crust (Hess Deep; Agrinier et al., 1995; Gillis et al., 2001) and drill holes (e.g., ODP Site 504; Alt et al., 1996). $\delta^{18}$ O values are higher than unaltered MORB compositions ( $5.6 \pm 0.2 \%$; Eiler, 2001) in the upper volcanic section of the crust but decrease to lower than mantle values in the lower sheeted dikes and gabbros (for profiles see Alt and Teagle, 2000).

The $\delta^{18} \mathrm{O}$ of the sheeted dike and gabbro layers is quite variable but the sheeted dikes at Hess Deep have an average value of 5.1\% (Gillis et al., 2001) and are as low as 2.9\% (Agrinier et al., 1995), significantly different than mantle values of 5.6\% (e.g., Alt et al., 1986; Eiler, 2001). Bulk melting of surrounding wall rock will result in $\delta^{18} \mathrm{O}$ values similar to the altered whole rock values, however, partial melts in equilibrium with the altered basalts will have oxygen isotope ratios generally less than mantle-equilibrated values, but higher (by 1\%; e.g., Muehlenbach and Byerly, 1982) than the altered basalt itself. Assimilation of these partial melts into fractionating magma will produce melts with oxygen isotope ratios between those of altered basalt and that expected from fractional crystallization alone. The $\delta^{18} \mathrm{O}$ value of the MOR andesites and dacites range from 5.38 to $6.19 \%$, which is much more variable than the spatially related basalts and lower than values predicted by fractional crystallization (Fig. 6).

Taylor (1968) suggested that to a first approximation, the effect of assimilation on oxygen isotope ratios can be determined using mass balance equations. Using results from Energy Constrained-Assimilation and Fractional Crystallization (EC-AFC) petrologic modeling calculations (Bohrson and Spera, 2001), which, unlike traditional AFC models, includes energy conservation in the formulation, the ratio of fractionating magma to partially melted assimilant $\left(\mathrm{M}_{\mathrm{f}} / \mathrm{M}_{\mathrm{a}}\right)$ in the dacites is $\sim 2.5: 1$ to 3.5:1 (Wanless et al., 2010). Using this range of ratios and assuming the evolved magma has a $\delta^{18} \mathrm{O}$ of $6.8 \%$ (largely due to fractionation of $\mathrm{Fe}-\mathrm{Mg}$ silicates and iron oxides) and an assimilant with a $\delta^{18} \mathrm{O}$ of $3.4 \%$ o to $5.6 \%$ (from partial melting of an altered basalt with a $\delta^{18} \mathrm{O}$ of $2.9 \%$ 。 to $5.1 \%$ ), the oxygen isotope ratio of the resultant magma would range from $5.8 \%$ o to $6.5 \%$. This range includes the average ratios observed in the dacites and is less than predicted solely as a consequence of crystal fractionation. Varying the ratio of the fractionated magma to assimilant $\left(\mathrm{M}_{\mathrm{f}} / \mathrm{M}_{\mathrm{a}}\right.$ of $2: 1$ to $\left.4: 1\right)$ or the $\delta^{18} \mathrm{O}$ value of the assimilant (from $2.9 \%$ to $6 \%$ ) can produce a range of compositions in the resulting magma (Fig. 9). To produce the lowest values observed at the OSC the assimilant must have a $\delta^{18} \mathrm{O}$ value of less than $4 \%$ or the $\mathrm{M}_{\mathrm{f}} / \mathrm{M}_{\mathrm{a}}$ must be lowered. Assuming the assimilated altered crust has the lowest $\delta^{18} \mathrm{O}$ value observed at Hess Deep of $2.9 \%$ (Agrinier et al., 1995) the range of $\delta^{18} \mathrm{O}$ values produced by AFC is $5.6 \%$ o to $5.9 \%$, assuming $\mathrm{M}_{\mathrm{f}} / \mathrm{M}_{\mathrm{a}}$ values from 2.5 to $3.5: 1$. If instead, the $\mathrm{M}_{\mathrm{f}} / \mathrm{M}_{\mathrm{a}}$ ratio is lowered to $2: 1$, than $\delta^{18} \mathrm{O}$ values of $5.4 \%$ 。 can be produced. Therefore, either increasing the amount of assimilant relative to fractionating magma or lowering the $\delta^{18} \mathrm{O}$ value of the assimilant can produce the range of $\delta^{18} \mathrm{O}$ values observed in dacites at the OSC.

\subsection{Potential sources of assimilant}

Despite growing evidence of crustal contamination on MORs, the nature of the assimilant and depth of the process remain poorly constrained, although some potential candidates can be eliminated if several geochemical parameters are considered. As mentioned above, $\mathrm{Cl} / \mathrm{K}_{2} \mathrm{O}$ and $\mathrm{H}_{2} \mathrm{O} / \mathrm{K}_{2} \mathrm{O}$ ratios provide a means to discriminate between sources of contamination on MOR because of the variable concentrations of these elements in possible assimilants (Kent et al., 1999). Potential contaminants on MOR include:

1) Altered basaltic crust: $\mathrm{Cl}=0.35$ wt.\% (Sparks, 1995); $\mathrm{H}_{2} \mathrm{O}=1.3$ wt.\% (Agrinier et al., 1995); $\mathrm{K}_{2} \mathrm{O}=0.08$ wt.\% (Stewart et al., 2002);

2) Seawater: $\mathrm{Cl}=1.935$ wt.\%, $\mathrm{H}_{2} \mathrm{O}=97.5$ wt.\%, $\mathrm{K}_{2} \mathrm{O}=0.04$ wt.\%; (Kent et al., 1999);

3) Saline brines of variable compositions, for example: $15 \% \mathrm{NaCl}$ brine $\left(\mathrm{Cl}=9.9\right.$ wt.\%, $\left.\mathrm{H}_{2} \mathrm{O}=85 \mathrm{wt} . \%, \mathrm{~K}_{2} \mathrm{O}=0.25 \mathrm{wt} . \%\right) ;$ and $50 \% \mathrm{NaCl}$ brine $\left(\mathrm{Cl}=30.3\right.$ wt.\%, $\mathrm{H}_{2} \mathrm{O}=50$ wt.\%, $\mathrm{K}_{2} \mathrm{O}=0.25$ wt.\%; Kent et al., 1999 and references therein for brine compositions);

4) Low-degree partial melts of altered ocean crust that have a range of compositions with relatively low $\mathrm{MgO}$, and high $\mathrm{Cl}, \mathrm{H}_{2} \mathrm{O}$ and $\mathrm{K}_{2} \mathrm{O}$ (Wanless et al., 2010).

Bulk mixing of altered basaltic crust or seawater with OSC basalt cannot produce the observed compositions of the MOR dacites (Fig. 4). Mixing of saline brines or partial melts of altered crust can explain the elevated $\mathrm{Cl} / \mathrm{K}_{2} \mathrm{O}$ ratios observed in the dacites, but is not consistent with the observed low $\mathrm{H}_{2} \mathrm{O} / \mathrm{K}_{2} \mathrm{O}$ ratios of the dacites, (Fig. 4), although the latter is likely influenced by $\mathrm{H}_{2} \mathrm{O}$ degassing. While discrimination between these two possible assimilants (brines versus crust) is difficult, only assimilation of altered ocean crust is consistent with major and trace element concentrations and petrologic modeling of MOR dacites (Wanless et al., 2010). Additionally, although le Roux et al. (2006) suggested that EPR MORB magmas were contaminated with brine at depths below the lava/dike (seismic layer $2 \mathrm{~A} / 2 \mathrm{~B})$ boundary and above the axial melt lens $(\sim 1400 \mathrm{~m}$ below seafloor) there is no consensus on the depth of brine formation or loci of storage at active ridges and therefore it is uncertain if saline brines are actually present within the zone of assimilation. Low $\mathrm{Cl}$ fluids may exist within the altered ocean crust but are not considered here because the high- $\mathrm{Cl}$ concentrations of the dacites makes this source of contamination unrealistic. Therefore, partially melted altered crust is the most likely source of contamination observed in the high-silica magmas and the low $\mathrm{H}_{2} \mathrm{O} / \mathrm{K}_{2} \mathrm{O}$ ratios in the dacites results from degassing. 


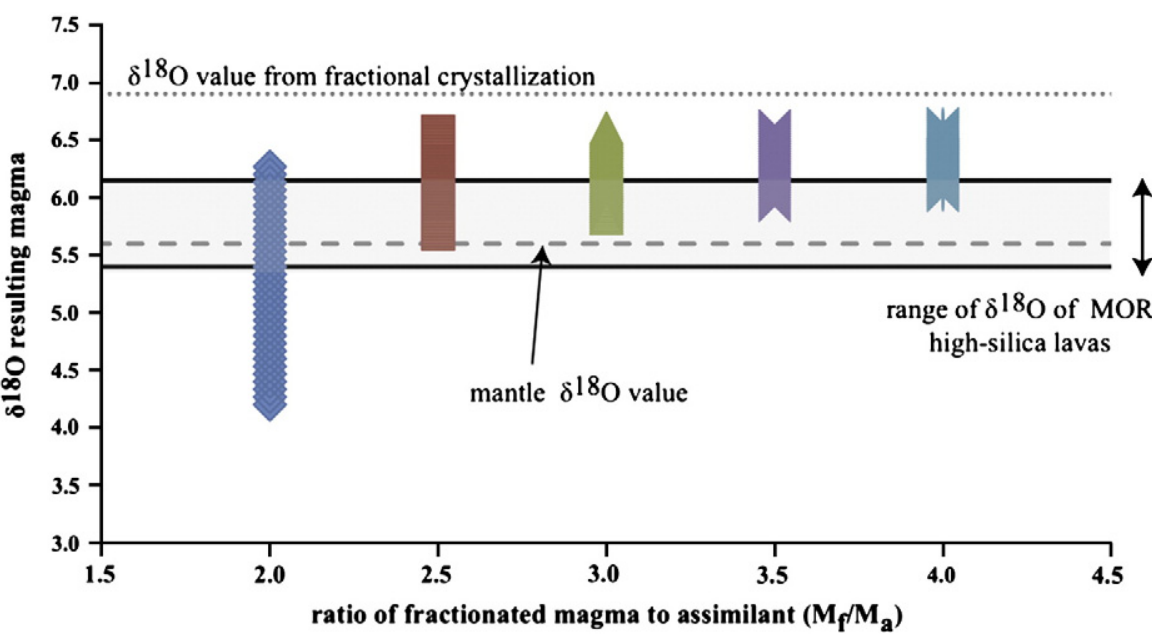

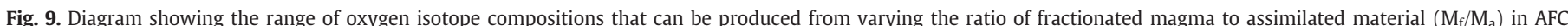

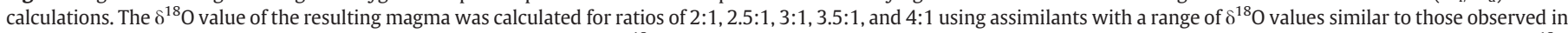

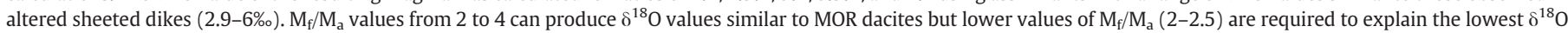
observed at the OSC. Small dotted line shows the $\delta^{18} \mathrm{O}$ value of magmas produced from fractional crystallization alone. Dashed line shows the mantle $\delta{ }^{18} \mathrm{O}$ value.

\subsection{Sulfur in MOR dacites}

Sulfur concentrations in the dacites are low (345 to $427 \mathrm{ppm}$ ) compared to those of basalts and basaltic andesites (Fig. 5), which is consistent with the relatively low $\mathrm{S}$ levels observed in high-silica lavas erupted at other ridges (Perfit et al., 1983). Possible explanations for the low $\mathrm{S}$ concentrations include fractional crystallization, formation of immiscible sulfide (Fe-S-O) liquid, magma mixing, assimilation, degassing, or some combination of the above. Sulfur concentrations increase in MORB magmas during fractional crystallization as $\mathrm{FeO}$ increases until the melt becomes saturated with respect to Fe-oxides, after which S contents decrease dramatically along with $\mathrm{FeO}$ (Mathez, 1976; Wallace and Carmichael, 1992). The decrease in S observed in the OSC andesites and dacites, which correlates with the decrease in $\mathrm{FeO}$, likely results from the low S solubility caused by decreasing $\mathrm{FeO}$ contents and decreasing temperature of the melt (Wallace and Carmichael, 1992). These factors lead to separation of a sulfide phase (Perfit et al., 1999). Nearly all MORB glasses are saturated with immiscible Fe-S-O liquid (Wallace and Carmichael, 1992). In the range from basalt to FeTi basalt, $\mathrm{S}$ does not increase nearly as much as would be expected if it were a highly incompatible element, implying that $\mathrm{S}$ content is being moderated by a sulfide phase. Lower $\mathrm{S}$ contents in andesites from the Galapagos Spreading Center are thought to result from the formation and fractionation of these immiscible monosulfide liquids (Perfit et al., 1999). Bulk assimilation may also contribute to lower $\mathrm{S}$ concentrations in the resulting melt, as altered sheeted dikes have lower $\mathrm{S}$ concentrations than typical MORB magmas (e.g. Alt et al., 1989), but low degree partial melts of the altered dikes have variable $\mathrm{S}$ contents depending on the degree of melting and the $S$ concentration of the assimilant. Finally, degassing may cause a decrease in $\mathrm{S}$ in the melt phase during transport to and eruption on the seafloor (e.g., Perfit et al., 1983, 1999). Therefore, while assimilation of altered material may produce lower $\mathrm{S}$ concentrations, sulfur is not a useful discriminator of assimilation due to the numerous processes that affect its concentrations.

\subsection{Formation of oceanic plagiogranites}

Plagiogranites are volumetrically small but ubiquitous siliceous components of the ocean crust and have been observed as veins and small intrusions in ophiolites (e.g. Pedersen and Malpas, 1984), in deep drill cores from the ocean crust (e.g. Casey, 1997; Dick et al., 2000), and as xenoliths in Icelandic lavas (Sigurdsson, 1977). There are also many examples of evolved plutonic rocks from slower spreading centers (e.g. Mid-Atlantic Ridge; Aumento, 1969, Southwest Indian Ridge; Dick et al., 2000). The origin of these veins and intrusions remains unclear but two main, non-exclusive hypotheses are: 1) partial melting of gabbroic crust (e.g. Koepke et al., 2004, 2007) and 2) extreme crystal fractionation of tholeiitic magmas (Beccaluva et al., 1999; Coleman and Donato, 1979; Niu et al., 2002).

The composition of oceanic plagiogranites varies considerably (Koepke et al., 2007), making a direct petrologic comparison with the MOR dacites difficult. However, trace element concentrations in the MOR dacites (Wanless et al., 2010) and the most evolved plagiogranite $\left(\mathrm{SiO}_{2}=63 \mathrm{wt} . \%\right)$ vein from the mid-Atlantic Ridge (Godard et al., 2009) are quite distinct, suggesting that the MOR dacites are not simply the extrusive equivalents of plagiogranite veins. For example, trace element enrichments observed in the MOR dacites (e.g. 1050 ppm Zr; 17 ppm Nb; 160 ppm Y) are much greater than those of the plagiogranite veins (e.g. 328 ppm Zr; 9.7 ppm Nb; 142 ppm Y). Also, although plagiogranite veins have positive $\mathrm{Zr}$ and $\mathrm{Hf}$ anomalies, they lack the negative $\mathrm{Nb}$ and $\mathrm{Ta}$ and elevated $\mathrm{U}$ and Th concentrations observed in MOR dacite glasses (Wanless et al., 2010). These variations in trace element patterns likely reflect differences in processes involved in the formation of these high-silica rocks. MOR dacites require both extensive fractional crystallization and assimilation of altered crustal material, while some plagiogranite veins may simply be the result of partial melting of unaltered ocean crust.

Zircons from plagiogranite veins can also have variable oxygen isotope ratios. Uniform mantle-like $\delta^{18} \mathrm{O}$ values of zircons collected from plagiogranite veins in the gabbroic crust at the mid-Atlantic and southwest Indian ridges ( $5.2 \pm 0.5 \%$ ) require no seawater contamination in the evolved melt at these depths (Grimes et al., 2011), but lower $\delta^{18} \mathrm{O}$ values in plagiogranite veins from the Oman ophiolite (average of $4.6 \pm 0.6 \%$ ) are thought to represent remelting of ocean crust that had been altered with respect to oxygen isotopes at high temperatures (Grimes et al., 2010). These studies suggest that highsilica lavas can form in a variety of different MOR settings and may have a range of compositions but that crustal melting is an important process in their petrogenesis.

\section{Conclusions}

Oxygen isotope values and volatile concentrations suggest the MOR dacites form by a combination of assimilation and fractional crystallization. Fast ascent rates for basaltic magmas from the $9^{\circ} \mathrm{N}$ OSC 
are required because the erupted lavas are supersaturated with $\mathrm{CO}_{2}$ In contrast, high-silica lavas have completely degassed any initial $\mathrm{CO}_{2}$, and variably degassed $\mathrm{H}_{2} \mathrm{O}$ prior to eruption and have relatively low $\mathrm{H}_{2} \mathrm{O} / \mathrm{K}_{2} \mathrm{O}$ ratios. These characteristics may result from slower ascent rates and/or lower effusion rates of high-silica magmas, and are consistent with the presence of large elongate vesicles and large extrusive pillow forms.

Volatile concentrations and $\delta^{18} \mathrm{O}$ in $9^{\circ} \mathrm{N}$ OSC lavas suggest crustal assimilation was a common process during their petrogenesis. Although evidence of assimilation in the $9^{\circ} \mathrm{N}$ OSC basalts is limited, more extreme signatures of assimilation are observed in high-silica andesites and dacites. This is consistent with previous petrogenetic models based on major and trace element studies (Wanless et al., 2010) that show chemical variations cannot be explained by fractional crystallization alone. Even though some volatile degassing is likely to have occurred during eruption of the high-silica lavas, $\mathrm{H}_{2} \mathrm{O}$ concentrations are up to two times higher in dacitic lavas compared to those expected based on calculated fractional crystallization trends, whereas $\mathrm{Cl}$ has excesses of seven to ten times predicted values. $\delta^{18} \mathrm{O}$ values are on average $\sim 1 \%$ 。 lower than ratios expected from fractional crystallization of ferromagnesian silicates and Fe-Ti oxide phases, consistent with assimilation of an additional component or components. The range in $\delta^{18} \mathrm{O}$ values can be explained by assimilation of oceanic crust altered to various degrees or by changing the ratio of the mass of fractionated magma to the mass of an assimilant with relatively low $\delta^{18} \mathrm{O}$ values.

Our chemical and isotopic data are most consistent with the partially melted, hydrothermally-altered oceanic crust as the source of the contamination. However, the involvement of small volumes of saline brines, produced during two-phase separation of hightemperature hydrothermal fluids, cannot be discounted. Vapor saturation pressures calculated from $\mathrm{H}_{2} \mathrm{O}-\mathrm{CO}_{2}$ data suggest that assimilation most likely occurs above the top of the seismicallyimaged melt lens, which at the $9^{\circ} \mathrm{N}$ OSC, corresponds approximately to the base of the sheeted dikes.

\section{Acknowledgments}

We thank the captain, officers and crew of the R/V Atlantis for all their help during cruise AT15-17, the MEDUSA2007 Science party (including S. White, K. Von Damm, D. Fornari, A. Soule, S. Carmichael, K. Sims, A. Zaino, A. Fundis, J. Mason, J. O'Brien, C. Waters, F. Mansfield K. Neely, J. Laliberte, E. Goehring, and L. Preston) for their diligence in collecting data and samples for this study. We thank the Jason II shipboard and shore-based operations group for their assistance in collecting these data and HMR for processing all DSL-120 sidescan and bathymetry collected during this cruise. Special thanks to J. W. Valley and the Stable Isotopes Lab at the University of Wisconsin-Madison for oxygen isotope analyses and thoughtful discussion throughout the preparation of this manuscript. Thanks to G. Kamenov and the UF Center for Isotope Geoscience for laboratory assistance. This manuscript benefited greatly from thoughtful and detailed reviews by Peter Michael and an anonymous reviewer. This research was supported by the National Science Foundation (grants OCE-0527075 to MRP, OCE0526120 to EMK, EAR-0509639, 0838058 to JWV for laser fluorination) and the Department of Energy (grant 93ER14389 to JWV).

\section{References}

Agrinier, P., Hekinian, R., Bideau, D., Javoy, M., 1995. O and H stable isotope compositions of oceanic crust and upper mantle rocks exposed in the Hess Deep near the Galapagos Triple Junction. Earth and Planetary Science Letters 136, 183-196.

Hydrothermal Alteration and Fluid Fluxes in Ophiolites and Oceanic Crust. In: Alt, J., Teagle, D.A.H. (Eds.), Geological Society of America, Boulder, CO. 273-297 pp.

Alt, J., Honnorez, J., Laverne, C., Emmerman, R., 1986. Hydrothermal alteration of a $1 \mathrm{~km}$ section through the upper oceanic crust, deep sea drilling project hole 504B: mineralogy, chemistry, and evolution of seawater-basalt interactions. Journal of Geophysical Research 91, 10,309-10,335.
Alt, J., Anderson, A.T., Bonnell, L., 1989. The geochemistry of sulfur in a $1.3 \mathrm{~km}$ section of hydrothermally altered oceanic crust, DSDP Hole 504B. Geochemica et Cosmochimica Acta 53, 1011-1023

Alt, J., Laverne, C., Vanko, D.A., Tartarotti, P., Teagle, D.A.H., Bach, W., Zuleger, E., Erzinger, J., Honnorez, J., Pezard, P., Becker, K., Salisbury, M.H., Wilkens, R.H., 1996. Hydrothermal Alteration of a Section of Upper Oceanic Crust in the Eastern Equatorial Pacific: A Synthesis of Results from Site 504 (DSDP Legs 69, 70, and 83, and ODP Legs 111,137, 140, and 148). Proceedings of the Ocean Drilling Program, Scientific Results 148, 417-434

Anderson, A.T., Clayton, R.N., Mayeda, T.K., 1971. Oxygen isotope thermometry of mafic igneous rocks. Journal of Geophysical Research 85, 715-729.

Aumento, F. 1969. Diorites from the mid-Atlantic ridge at $45^{\circ} \mathrm{N}$. Science $165,1112-1113$. Batiza, R., Niu, Y., 1992. Petrology and magma chamber processes at the East Pacific Rise $9^{\circ} 30^{\prime} \mathrm{N}$. Journal of Geophysical Research 97, 6779-6797.

Bazin, S., Harding, A.J., Kent, G.M., Orcutt, J.A., Tong, C.H., Pye, J.W., Singh, S.C., Barton, P.J., Sinha, M.C., White, R.S., Hobbs, R.W., Van Avendonk, H.J.A., 2001. Threedimensional shallow crustal emplacement at the 903' $\mathrm{N}$ overlapping spreading center on the East Pacific Rise: correlations between magnetization and tomographic images. Journal of Geophysical Research 106, 16,101-16,117.

Beccaluva, L., Chinchilla-Chaves, A.L., Coltorti, M., Giunta, G., Siena, F., Vaccaro, C., 1999. Petrological and structural significance of the Santa Elena-Nicoya ophiolitic complex in Costa Rica and geodynamic implications. Contributions to Mineralogy and Petrology 11, 1091-1107.

Berndt, M.E., Seyfreid, W.E.J., 1990. Boron, bromine, and other trace elements as clues to the fate of chlorine in mid-ocean ridge vent fluids. Geochemica et Cosmochimica Acta 54, 2235-2245.

Bindeman, I.N., 2008. Oxygen isotopes in mantle and crustal magmas as revealed by single crystal analysis. Reviews in Mineralogy and Geochemistry 69, 445-478.

Bohrson, W.A., Spera, F., 2001. Energy-constrained open-system magmatic processes II: application of energy constrained assimilation-fractional crystallization (EC-AFC) model to magmatic systems. Journal of Petrology 42, 1019-1041.

Carbotte, S.M., Macdonald, K.C., 1992. East Pacific Rise $8^{\circ}-10^{\circ} 30^{\prime} \mathrm{N}$ : evolution of ridge segments and discontinuities from SeaMARC II and three-dimensional magnetic studies. Journal of Geophysical Research 97, 6959-6982.

Casey, J.F. (Ed.), 1997. Comparison of Major- and Trace-element Geochemistry of Abyssal Peridotites and Mafic Plutonic Rocks with Basalts from the MARK Region of the Mid-Atlantic Ridge. Ocean Drilling Program, College Station. 181-241 pp.

Christie, D.M., Sinton, J.M., 1981. Evolution of abyssal lavas along propagating segments of the Galapagos Spreading Center. Earth and Planetary Science Letters 56, 321.

Coleman, R.G., Donato, M.M., 1979. Oceanic plagiogranite revisited, in Barker, F., ed. Trondhjemites, dacites and related rocks: Developments in Petrology 6: Amsterdam, Elsevier, pp. 149-168.

Coogan, L.A., 2003. Contaminating the lower crust in the Oman ophiolite. Geology 31, 1065-1068.

Coogan, L.A., Mitchell, N.C., O'Hara, M.J., 2003. Roof assimilation at fast spreading ridges: an investigation combining geochemical, and field evidence. Journal of Geophysical Research 108, 1-14.

Detrick, R.S., Buhl, P., Vera, E., Mutter, J., Orcutt, J.A., Madsen, J., Brocher, T., 1987. Multichannel seismic imaging of a crustal magma chamber along the East Pacific Rise. Nature 326, 35-41.

Dick, J.B., Natland, J.H., Alt, J., Bach, W., Bideau, D., Gee, J.S., Haggas, S., Hertogen, J.G.H., Hirth, G., Holm, P.M., Ildefonse, B., Iturrino, G.J., John, B.E., Kelley, D.S., Kikawa, E., Kingdon, A., le Roux, P.J., Maeda, J., Meyer, P.S., Miller, D.J., Naslund, H.R., Niu, Y., Robinson, P.T., Snow, J., Stephen, R.A., Trimby, P.W., Worm, H.U., Yoshinobu, A., 2000. A long in situ section of the lower ocean crust: results of ODP Leg 176 drilling at the Southwest Indian Ridge. Earth and Planetary Science Letters 179, 31-51.

Dixon, J.E., Pan, V., 1995. Determination of the molar absorptivity of dissolved carbonate in basanitic glass. American Mineralogist 80, 1339-1342.

Dixon, J.E., Clague, D.A., 2001. Volatiles in Basaltic Glasses from Loihi Seamount, Hawaii: Evidence for a Relatively Dry Plume Component. Journal of Petrology 42, 627-654.

Dixon, J.E., Stolper, E.M., Delaney, J.R., 1988. Infrared spectroscopic measurements of $\mathrm{CO} 2$ and $\mathrm{H} 2 \mathrm{O}$ in Juan de Fuca Ridge basaltic glasses. Earth and Planetary Science Letters 90, 87-104.

Dixon, J.E., Stolper, E.M., Holloway, J.R., 1995a. An experimental study of water and carbon dioxide solubilities in mid-ocean ridge basaltic liquids. Part I: calibration and solubility models. Journal of Petrology 36, 1607-1631.

Dixon, J.E., Stolper, E.M., Holloway, J.R., 1995b. An experimental study of water and carbon dioxide solubilities in mid-ocean ridge basaltic liquids. Part II: applications to degassing. Journal of Petrology 36, 1633-1646.

Dunn, R.A., Toomey, D.R., Detrick, R.S., Wilcock, W.S.D., 2001. Continuous mantle melt supply beneath an overlapping spreading center on the East Pacific Rise. Science 291, 1955-1958.

Eiler, J.M., 2001. Oxygen isotope variations of basaltic lavas and upper mantle rocks. Reviews in Mineralogy and Geochemistry 43, 319-364.

Eiler, J.M., Farley, K.A., Valley, J., Hofmann, A.W., Stolper, E.M., 1996. Oxygen isotope constraints on the sources of Hawaiian volcanism. Earth and Planetary Science Letters $144,453-468$.

Fornari, D.J. 2003. A new deep-sea towed digital camera and multi-rock coring system. EOS, Transactions American Geophysical Union 84, 69-76.

Garcia, M.O., Muenow, D.W., Aggrey, K.E., O'Neil, J.R., 1998. Major element, volatile and stable isotope geochemistry of Hawaiian submarine tholeiitic glasses. Journal of Geophysical Research 94, 10,525-10,538.

Gautason, B., Muehlenbach, K., 1998. Oxygen isotopic fluxes associated with hightemperature processes in the rift zones of Iceland. Chemical Geology 145, 275-286.

Ghiorso, M.S., Sack, R.O., 1995. Chemical mass transfer in magmatic processes. IV. A revised and internally consistent thermodynamic model for the interpolation and 
extrapolation of liquid-solid equilibria in magmatic systems at elevated temperatures and pressures. Contributions to Mineralogy and Petrology 119, 197-212.

Gillis, K.M., 2008. The roof of an axial magma chamber: a hornfelsic heat exchanger. Geology 36, 299-302.

Gillis, K.M., Coogan, L.A., 2002. Anatectic migmatites from the roof of an ocean ridge magma chamber. Journal of Petrology 43, 2075-2095.

Gillis, K.M., Muehlenbach, K., Stewart, M., Gleeson, T., Karson, J.A., 2001. Fluid flow patterns in fast spreading East Pacific Rise crust exposed at Hess Deep. Journal of Geophysical Research 106, 26,311-26,329.

Godard, M., Awaji, S., Hansen, H., Hellebrand, E., Brunelli, D., Johnson, K.T.M., Yamasaki, T., Maeda, J., Abratis, M., Christie, D.M., Kato, Y., Mariet, C., Rosner, M., 2009. Geochemistry of a long in-situ section of intrusive slow-spread oceanic lithosphere: results from IODP Site U1309 (Atlantis Massif, $30^{\circ} \mathrm{N}$ Mid-Atlantic Ridge). Earth and Planetary Science Letters 279, 110-122.

Goss, A., Perfit, M., Ridley, W.I., Rubin, K.H., Kamenov, G., Soule, A.S., Fundis, A., Fornari, D.J., 2010. Geochemistry of lavas from the 2005-2006 eruption at the East Pacific Rise, $9^{\circ} 46^{\prime} \mathrm{N}-9^{\circ} 56^{\prime} \mathrm{N}$ : implications for ridge crest plumbing and decadal changes in magma chamber compositions. Geochemistry, Geophysics, Geosystems 11, 1-35.

Grimes, C.B., Ushikubo, T., Valley, J.W., 2010. Low $\delta 180$ (Zrc) in plagiogranites at Oman: evidence for remelting. Geochemica et Cosmochimica Acta 74, A355.

Grimes, C.B., Ushikubo, T., John, B.E., Valley, J., 2011. Uniformly mantle-like $\delta^{18} \mathrm{O}$ in zircons from oceanic plagioranites and gabbros. Contributions to Mineralogy and Petrology 161, 13-33.

Harding, A.J., Kent, A.J.R., Orcutt, J.A., 1993. A multichannel seismic investigation of upper crustal structure at $9^{\circ} \mathrm{N}$ on the East Pacific Rise: implications for crustal accretion. Journal of Geophysical Research 98, 13,925-13,944.

Johnson, E.R., Wallace, P., Delgado Granados, H., Manea, V.C., Kent, A.J.R., Bindeman, I.N., Donegan, C.S., 2009. Subduction-related volatile recycling and magma generation beneath Central Mexico: insights from melt inclusions, oxygen isotopes and geodynamic models. Journal of Petrology 50, 1729-1764.

Kelley, D.S., Delaney, J.R., 1987. Two-phase separation and fracturing in mid-ocean ridge gabbros at temperatures greater than $700{ }^{\circ} \mathrm{C}$. Earth and Planetary Science Letters 83, 53-66.

Kent, A.J.R., Harding, A.J., Orcutt, J.A., 1993. Distribution of magma beneath the East Pacific Rise near $9^{\circ} 03^{\prime} \mathrm{N}$ overlapping spreading center from forward modeling of CDP data. Journal of Geophysical Research 98, 13,971-13,995.

Kent, A.J.R., Norman, M.D., Hutcheon, I.D., Stolper, E.M., 1999. Assimilation of seawaterderived components in an oceanic volcano: evidence from matrix glasses and glass inclusions from Loihi seamount, Hawaii. Chemical Geology 156, 299-319.

Kent, G.M., Singh, S.C., Harding, A.J., Sinha, M.C., Orcutt, J.A., Barton, P.J., White, R.S., Bazin, S., Hobbs, R.W., Tong, C.H., Pye, J.W., 2000. Evidence from three-dimensional seismic reflectivity images for enhanced melt supply beneath mid-ocean ridge discontinuities. Nature 406, 614-618.

Kent, A.J.R., Peate, D.W., Newman, S., Stolper, E.M., Pearce, J.A., 2002. Chlorine in submarine glasses from the Lau Basin: seawater contamination and constraints on the composition of slab-derived fluids. Earth and Planetary Science Letters 202, 361-377.

Koepke, J., Feig, S.T., Snow, J., Freise, M., 2004. Petrogenesis of oceanic plagiogranites by partial melting of gabbros: an experimental study. Contributions to Mineralogy and Petrology 146, 414-432.

Koepke, J., Berndt, J., Feig, S.T., Holtz, F., 2007. The formation of $\mathrm{SiO}_{2}$-rich melts within the deep oceanic crust by hydrous partial melting of gabbros. Contributions to Mineralogy and Petrology 153, 67-84.

Langmuir, C.H., Bender, J.F., Batiza, R., 1986. Petrological and tectonic segmentation of the East Pacific Rise, $5^{\circ} 30^{\prime}-14^{\circ} 30^{\prime} \mathrm{N}$. Nature $322,422-429$.

le Roux, P.J., Shirey, S.B., Hauri, E.H., Perfit, M.R., Bender, J.F., 2006. The effects of variable sources, processes and contaminants on the composition of northern EPR MORB (8-10 N and $12-14 \mathrm{~N})$ : evidence from volatiles $\left(\mathrm{H}_{2} \mathrm{O}, \mathrm{CO}_{2}, \mathrm{~S}\right)$ and halogens $(\mathrm{F}, \mathrm{Cl})$. Earth and Planetary Science Letters 251, 209-231.

Macdonald, K.C., Fox, P.J., 1983. Overlapping spreading centers: new accretion geometry on the East Pacific Rise. Nature 302, 55-58.

Mandeville, C.W., Webster, J.D., Rutherford, M.J., Taylor, B.E., Timbal, A., Faure, K., 2002. Determination of molar absorptivities for infrared absorption bands of $\mathrm{H} 2 \mathrm{O}$ in andesitic glass. American Mineralogist 87, 813-821.

Mathez, E.A., 1976. Sulfur solubility and magmatic sulfides in submarine basalt glass. Journal of Geophysical Research 81.

Matsuhisa, Y., Matsubaya, O., Sakai, H., 1973. Oxygen isotope variations in magmatic differentiation processes of the volcanic rocks in Japan. Contributions to Mineralogy and Petrology 39, 277-288.

Michael, P., Cornell, W.C., 1998. Influence of spreading rate and magma supply on crystallization and assimilation beneath mid-ocean ridges: evidence from chlorine and major element chemistry of mid-ocean ridge basalts. Journal of Geophysical Research 103, 18,325-18,356.

Michael, P., Schilling, J.G., 1989. Chlorine in mid-ocean ridge magmas: evidence for assimilation of seawater-influenced components. Geochimica Cosmochemica Acta 53, 3131-3143.
Muehlenbach, K., Byerly, G.R., $1982 .{ }^{18}$ O-Enrichment of silicic magmas caused by crystal fractionation at the Galapagos Spreading Center. Contributions to Mineralogy and Petrology 79, 76-79.

Muehlenbach, K., Clayton, R.N., 1972. Oxygen isotope studies of fresh and weathered submarine basalts. Canadian Journal of Earth Science 2, 172-184.

Newman, S., Lowenstern, J.B., 2002. VOLATILECALC: a silicate melt- $\mathrm{H}_{2} \mathrm{O}-\mathrm{CO}_{2}$ solution model written in Visual Basic for excel. Computers and Geosciences 28, 597-604.

Niu, Y., Gilmore, T., Mackie, S., Greig, A., Bach, W., 2002. Mineral chemistry, whole-rock compositions, and petrogenesis of Leg 176 gabbros: data and discussion. College Station, Ocean Drilling Program.

O'Hara, M.J., 1977. Geochemical evolution during fractional crystallization of a periodically refilled magma chamber. Nature 266, 503-507.

Pedersen, R.B., Malpas, J., 1984. The origin of oceanic plagiogranites from the Karmoy ophiolite, western Norway. Contributions to Mineralogy and Petrology 88, 36-52.

Perfit, M.R., Fornari, D.J., Malahoff, A., Embley, R.W., 1983. Geochemical studies of abyssal lavas recovered by DSRV Alvin from Eastern Galapagos Rift, Inca Transform, and Ecuador Rift 3. Trace element abundances and petrogenesis. Journal of Geophysical Research 88, 10,551-10,572.

Perfit, M.R., Fornari, D.J., Smith, M.C., Bender, J.F., Langmuir, C.H., Hayman, N.W., 1994 Small-scale spatial and temporal variations in mid-ocean ridge crest magmatic processes. Geology 22, 375-379.

Perfit, M.R., Ridley, W.I., Jonasson, I.R., 1999. Geologic, petrologic and geochemica relationships between magmatism and massive sulfide mineralization along the eastern Galapagos Spreading Center. Reviews in Economic Geology 8, 75-99.

Reynolds, J.R., 1995. Segment-scale systematic of mid-ocean ridge magmatism and geochemistry. Palisades: Columbia University, 483.

Sempere, J.-C., Macdonald, K.C., 1986. Deep-tow studies of the overlapping spreading centers at $903^{\prime} \mathrm{N}$ on the East Pacific Rise. Tectonics 5, 881-900.

Sigurdsson, H., 1977. Generation of Icelandic rhyolites by melting of plagiogranites in the oceanic layer. Nature 269, 25-28.

Smith, M.C., Perfit, M.R., Fornari, D.J., Ridley, W.I., Edwards, M.H., Kurras, G.J., Von Damm, K.L., 2001. Magmatic processes and segmentation at a fast spreading midocean ridge: detailed investigation of an axial discontinuity on the East Pacific Rise crest at $9^{\circ} 37^{\prime}$ N. Geochemistry, Geophysics, Geosystems 2, 1-32.

Sparks, J.W., 1995. Geochemistry of the Lower Sheeted Dike Complex, Hole 504B, Leg 140. Proceedings of the Ocean Drilling Program. Scientific Results 137 (140), 81-97.

Spicuzza, M.J., Valley, J.W., Kohn, M.J., Girard, J.P., Fouillac, A.M., 1998. The rapid heating defocused beam technique: a $\mathrm{CO}_{2}$-laser-based method for highly precise and accurate determination of $\delta^{18} \mathrm{O}$ values of quartz. Chemical Geology 144, 195-203.

Stewart, M.A., Klein, E.M., Karson, J.A., 2002. Geochemistry of dikes and lavas from the north wall of the Hess Deep Rift: insights into the four-dimensional character of crustal construction at fast spreading mid-ocean ridges. Journal of Geophysical Research 107, 2238.

Sun, W.D., Binns, R.A., Fan, A.C., Kamenetsky, V.S., Wysoczanski, R., Wei, G.J., Hu, Y.H., Arculus, R.J., 2007. Chlorine in submarine volcanic glasses from the eastern Manus basin. Geochemica et Cosmochimica Acta 71, 1542-1552.

Taylor, H.P.J., 1968. The oxygen isotope geochemistry of igneous rocks. Contributions to Mineralogy and Petrology 19, 1-71.

Tong, C.H., Pye, J.W., Barton, P.J., White, R.S., Sinha, M.C., Singh, S.C., Hobbs, R.W., Bazin S., Harding, A.J., Kent, G.M., Orcutt, J.A., 2002. Asymmetric melt sills and upper crustal construction beneath overlapping ridge segments: implications for the development of melt sills and ridge crests. Geology 30, 83-86.

Unni, C.K., Schilling, J.G., 1978. Cl and Br degassing by volcanism along the Reykjanes Ridge and Iceland. Nature 272, 19-23.

Valley, J., Kitchen, N., Kohn, M.J., Niendorf, C.R., Spicuzza, M.J., 1995. UWG-2, a garnet standard for oxygen isotope ratios: strategies for high precision and accuracy with laser heating. Geochemica et Cosmochimica Acta 59, 5223-5231.

Von Damm, K.L., Buttermore, L.G., Oosting, S.E., Bray, A.M., Fornari, D.J., Lilley, M., Shanks, W.C., 1997. Direct observation of the evolution of a seafloor 'black smoker' from vapor to brine. Earth and Planetary Science Letters 149, 101-111.

Wallace, P., Carmichael, I.S.E., 1992. Sulfur in basaltic magmas. Geochemica et Cosmochimica Acta 56, 1863-1874.

Wanless, V.D., Perfit, M.R., Ridley, W.I., Klein, E.M., 2010. Dacite petrogenesis on midocean ridges: evidence for oceanic crustal melting and assimilation. Journal of Petrology 51, 2377-2410.

Webster, J.D., Kinzler, R.J., Mathez, E.A., 1999. Chloride and water solubility in basalts and andesite melts and implications for magmatic degassing. Geochemica et Cosmochimica Acta 63, 729-738.

White, S.M., Mason, J.L., Macdonald, K.C., Perfit, M.R., Wanless, V.D., Klein, E.M., 2009 Significance of widespread low effusion rate eruptions over the past two million years for delivery of magma to the overlapping spreading centers at $9^{\circ} \mathrm{N}$ East Pacific Rise. Earth and Planetary Science Letters 280, 175-184. 